\title{
Efficacy of SARS-CoV-2 vaccine in thoracic cancer patients: a prospective study supporting a third dose in patients with minimal serologic response after two vaccine doses
}

Valérie Gounant, MD, MSc. ${ }^{1,2^{*}}$, Valentine Marie Ferré, PharmD, MSc. ${ }^{3^{*}}$, Ghassen Soussi, MD ${ }^{1,2}$, Charlotte Charpentier, PharmD, $\mathrm{PhD}^{3}$, Héloïse Flament, Pharm D, $\mathrm{PhD}^{4}$, Nadhira Fidouh, PharmD ${ }^{3}$, Gilles Collin, Msc. ${ }^{3}$, Céline Namour, MSc. ${ }^{1,2}$, Sandra Assoun,, ${ }^{1,2}$ MD, MSc, Alexandra Bizot, ${ }^{1,2}$ MD, MSc., Zohra Brouk, $\mathrm{PhD}^{1,2}$, Eric Vicaut, MD, $\mathrm{PhD}^{5}$, Luis Teixeira, MD, $\mathrm{PhD}^{6}$, Diane Descamps, $\mathrm{MD}, \mathrm{PhD}^{3}$, and Gérard Zalcman, $\mathrm{MD}, \mathrm{PhD}^{1,2,7 \uparrow}$

1- Université de Paris, North-Paris Cancer University Institute, Thoracic Oncology Department, Bichat-Claude Bernard Hospital, Assistance Publique-Hôpitaux de Paris (APHP.Nord), 46 rue Henri Huchard, Paris, France

2- INSERM Centre d'Investigation Clinique 1425, Bichat-Claude Bernard Hospital, Assistance Publique-Hôpitaux de Paris (AP-HP.Nord), 46 rue Henri Huchard, Paris, France

3- Université de Paris, Virology Department, INSERM UMR1137 "Infection, Antimicrobials, Modelling, Evolution", Bichat-Claude Bernard Hospital, Assistance Publique-Hôpitaux de Paris (AP-HP.Nord), 46 rue Henri Huchard, Paris, France

4- Université de Paris, Hematology and Immunology Department, INSERM-U1149, Research Center on Inflammation (CRI) Bichat-Claude Bernard Hospital, Assistance Publique-Hôpitaux de Paris (AP-HP.Nord), 46 rue Henri Huchard, Paris, France

5- Université de Paris, Biostatistics and Clinical Research Department, Lariboisière Hospital (AP-HP.Nord), 2 rue Amboise Paré, 75018 Paris, France

6- Université de Paris, North-Paris Cancer University Institute, Breast Diseases Centre, INSERM U976, HIPI, "Pathophysiology of Breast Cancer Team", Saint-Louis Hospital, Assistance Publique-Hôpitaux de Paris (AP-HP.Nord), 1 avenue Claude Vellefaux, 75010 Paris, France

7- INSERM U830 "Cancer, Heterogeneity Plasticity", Curie Institute Research Centre, 26 rue d'Ulm, 75231 Paris cedex 05, France

* both authors equally contributed

"To whom correspondence must be addressed: 
Prof. G. Zalcman

Service d' Oncologie Thoracique

Hôpital Bichat-Claude Bernard

46 rue Henri Huchard

FR-75018 Paris

gerard.zalcman@aphp.fr

Key-words: lung cancer, chemotherapy, immune checkpoint inhibitors, COVID-19, Sars-CoV2 vaccination, mRNA vaccine, antibody response

\section{Authors contribution:}

conceptualization: GZ, VG, DD, LT; supervision: GZ, VG; data curation: GZ, CM, ZB, GS, VG, VMF; Formal analysis: GZ, GS, VG, EV, VMF; Funding acquisition: GZ, LT, HF, DD,

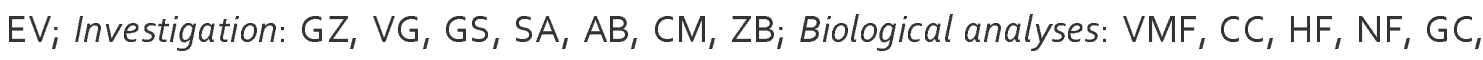
DD; Statistical analyses: GS, EV; original draft: $G Z$; review \& editing: GZ, VG, GS, VMF, HF $\mathrm{DD}, \mathrm{EV}, \mathrm{EV}_{i}$ final MS approbation: all authors.

\section{Conflict of interest statement:}

Valentine Marie Ferré, Ghassen Soussi, Charlotte Charpentier, Héloïse Flament, Nadhira Fidouh, Gilles Collin, Céline Namour, Sandra Assoun, Alexandra Bizot, Zohra Brouk, Eric Vicaut, Luis Teixeira have nothing to disclose.

Gérard Zalcman received research grants from Roche-France, BMS, Takeda outside of the submitted work, perceived fees from BMS, Astra-Zeneca, Pfizer, Borhinger-Ingelheim outside the submitted work and reimbursement for international meetings assistance from Abbvie, MSD, Astra-Zeneca, BMS, Roche-France;

Valérie Gounant reports personal fees from MSD, Chugai, Novartis, and Boehringer; personal fees and non-financial support from Astra Zeneca, BMS, Takeda, and Pfizer; grants, personal fees, and non-financial support from Roche, all outside the submitted work;

Diane Descamps reports fees from Viiv-healthcare, Gilead-Sciences, Janssen-Cilag outside the submitted work; 


\section{Abstract}

\section{Hypothesis}

Coronavirus disease 2019 (COVID-19) resulted in a 30\% mortality rate in thoracic cancer patients. Given that cancer patients were excluded from serum anti-severe acute respiratory syndrome coronavirus 2 (SARS-CoV2) vaccine registration trials, it is still unknown whether they would develop a protective anti-spike antibody response following vaccination. This prospective vaccine monitoring study primarily aimed to assess humoral responses to SARS-CoV2 vaccine in thoracic cancer patients.

\section{Methods}

SARS-CoV2-spike antibodies were measured using Abbot ARCHITECT SARS-CoV2 IgG immunoassay, prior to first injection of BNT162b2 mRNA vaccine, as well as at Week 4 , and two-to-sixteen weeks after second vaccine dose. The factors associated with antibody response were analyzed.

\section{Results}

Overall, 306 patients, with a median age of 67.0 years (IQR=58-74), were vaccinated. Of these, 283 patients received two vaccine doses at 28-day intervals. After 4.7-month median follow-up, seven patients (2.3\%) contracted proven symptomatic SARS-CoV-2 infection, with rapid favorable evolution. Of 269 serological results available beyond Day 14 post-second vaccine dose, 17 (6.3\%) were still negative $(<50 \mathrm{AU} / \mathrm{mL}$ ) (arbitrary units $/ \mathrm{mL}$ ), while $34(11 \%)$ were $<300$ $\mathrm{AU} / \mathrm{mL}\left(12.5^{\text {th }}\right.$ percentile). In multivariate analysis, only age and chronic corticosteroid treatment were significantly associated with a lack of immunization. Thirty patients received a third vaccine dose, with only three patients showing persistent negative serology thereafter, whereas the others demonstrated clear seroconversion.

\section{Conclusion}

SARS-CoV2 vaccines were shown to be efficient in thoracic cancer patients, most of them being immunized after two doses. A third shot given to $1 \%$ of patients with persistent low antibody titers resulted in a $88 \%$ immunization rate. 
medRxiv preprint doi: https://doi.org/10.1101/2021.08.12.21261806; this version posted August 13, 2021. The copyright holder for this preprint (which was not certified by peer review) is the author/funder, who has granted medRxiv a license to display the preprint in perpetuity.

It is made available under a CC-BY-NC-ND 4.0 International license .

\section{Introduction}

Coronavirus disease 2019 (COVID-19) is associated with a dramatic 30\% mortality rate in thoracic cancer patients ${ }^{1,2,3}$. The Chinese series reported mortality rates of $29-39 \%,{ }^{4-6}$ compared with $0.7-8.0 \%$ case fatality rates in their general population ${ }^{7-11}$. Lung cancer patients should therefore be given priority for severe acute respiratory syndrome coronavirus 2 (SARS-CoV-2) vaccination. Nonetheless, active cancer condition and immunosuppressive therapy constituted non-inclusion criteria for SARS-CoV-2 vaccine registration trials, and scarcely anything is known about the vaccine effectiveness in cancer populations. Moreover, the antibody response after influenza vaccination was previously shown to be lower in cancer patients versus healthy controls, especially concerning people aged $\geq 65$ years $^{12}$. Notably, two doses of influenza vaccine were required in cancer patients to attain the same serum protection rate than in healthy controls, with on-going chemotherapy or corticosteroids resulting in lower protection ${ }^{13}$. Similarly, a meta-analysis on influenza vaccine effectiveness in cancer patients exhibited significantly reduced seroconversion ( $\geq$ four-fold rise) in comparison with vaccinated immunocompetent controls $(0.31 ; 95 \% \mathrm{Cl}: 0.22-0.43)^{14}$. Vaccination timing remains unclear too. Upon chemotherapy, the mid-point between two cycles was empirically selected for the vaccine shot. Moreover, as immunotherapy has become an essential component of lung cancer treatment, only little is known concerning undesirable effects, although no short-term reactogenicity following influenza vaccination occurred in patients under immune checkpoints inhibitors $(\mathrm{ICls})^{15}$. Both mRNA vaccine registration trials reported $94 \%$ effectiveness against severe COVID19 in healthy volunteers, $\geq 14$ days post-second booster (Day 21 for Pfizer BNT162b2 ${ }^{16}$ or Day 28 for Moderna mRNA$1273^{17,}{ }^{18}$ ). Concerning adenovirus-based vaccines (one shot of Janssen 
medRxiv preprint doi: https://doi.org/10.1101/2021.08.12.21261806; this version posted August 13, 2021. The copyright holder for this preprint (which was not certified by peer review) is the author/funder, who has granted medRxiv a license to display the preprint in perpetuity. It is made available under a CC-BY-NC-ND 4.0 International license.

Ad26.COV2. ${ }^{19}$ or two doses of Astra-Zeneca ChAdOx1nCov-19 vaccines ${ }^{20,}{ }^{21}$ ), slightly lower rates were reported. Similar protection rates against severe COVID19 were confirmed in real-life by population-based Israeli and Scottish studies for Pfizer BNT162b2 or ChAdOx1nCov-1922, 23 . Yet, these data cannot be extrapolated to cancer patients undergoing anti-cancer treatment. Duration of anti-SARS-CoV-2spike (anti-S) detection was at least 8 months in healthy volunteers ${ }^{24}$. It is unclear whether such duration is applicable to cancer patients receiving immunosuppressing drugs. Early January 2021, vaccination was made available in France. To increase first vaccine dose availability, French Health authorities recommended a 28-day interval for both mRNA vaccines, with a 42-day interval for healthy people, this delayed second dosing being debatable ${ }^{25,26}$. Due to uncertainties concerning vaccination of cancer patients, the observational COVIDVAC-OH study (clinical.trials.gov NCT04776005) was launched, sponsored by Paris University Hospitals. This study sought to investigate SARS-CoV-2 vaccination's (mainly mRNA-based vaccines) effectiveness in over 1100 consecutive patients with solid cancers or hematological malignancies, at North-Paris University Cancer center. This report concerns 306 thoracic cancer patients.

\section{METHODS}

\section{Trial design, objectives, and participants}

We conducted a prospective study involving thoracic cancer patients followed-up in Bichat Hospital, from January 26 to July 28, 2021. Patients diagnosed with thoracic cancer and deemed eligible (no known COVID-19 infection within <last three months; life expectancy $>3$ months; lack of known allergy to previous vaccines) were 
medRxiv preprint doi: https://doi.org/10.1101/2021.08.12.21261806; this version posted August 13, 2021. The copyright holder for this preprint (which was not certified by peer review) is the author/funder, who has granted medRxiv a license to display the preprint in perpetuity.

It is made available under a CC-BY-NC-ND 4.0 International license .

identified from medical records. They were contacted and offered to be vaccinated. If they accepted and in the absence of contra-indications, they were attended vaccination sessions in the outpatient clinic, according to priority sequencing, as follows: first elderly patients aged $\geq 75$ years and those receiving chemotherapy; patients receiving immune checkpoint inhibitors $(\mathrm{ICl})$; patients with pneumonectomy or chronic radiation pneumonitis; patients on oral tyrosine kinase targeted therapy (TKIs); patients without systemic therapy. They were given a written information leaflet on COVID19 mRNA BNT162b2 vaccine, and on serological and hematological blood tests to be performed at first dose (Day 0), at second dose (Day 28), and at least 2 weeks post-booster dose (Day 42). All patients could oppose blood samplings and still undergo vaccine injections. Recommendations to keep facial masks and social distancing were given. All patients were registered into National Health Insurance computed COVID-19 vaccine database, with national identification number, complete identity, main underlying conditions, and vaccine batch number. Following blood sampling and vaccine injection, patients were followed-up for 15 minutes under medical surveillance ${ }^{27}$. This study was approved by the Comité d'Evaluation de l'Ethique des projets de Recherche Biomedicale (CEERB, IRB00006477) of University Hospitals Paris-North Val-de-Seine, Paris 7 University, Assistance Publique-Hôpitaux de Paris (AP-HP) upon the approval number $\mathrm{N}^{\circ} \mathrm{CER}$ 2021-72. In the case of COVID-19-suggestive symptoms, patients were instructed to promptly inform the medical team and perform nasopharyngeal SARS-CoV-2 RTPCR swab testing. At second vaccination visit, they were questioned about undesirable events post-first vaccination and symptoms evoking COVID-19. Some patients $(n=16)$ were vaccinated by their general practitioner or in a governmentcertified vaccination center. No blood sampling was available for these patients at 
medRxiv preprint doi: https://doi.org/10.1101/2021.08.12.21261806; this version posted August 13, 2021. The copyright holder for this preprint (which was not certified by peer review) is the author/funder, who has granted medRxiv a license to display the preprint in perpetuity.

It is made available under a CC-BY-NC-ND 4.0 International license.

Days 0 and 28. If they agreed, they underwent blood sampling in the post-booster period and were included in our study.

To set up the technical conditions for SARS-CoV-2 anti-nucleocapsid $(\mathrm{N})$ index and anti-Spike antibody determination, 18 control subjects from Hôpital Bichat staff, without previous COVID-19 symptoms or PCR-proved SARS-CoV-2 infection, provided their written consent for blood sampling. This occurred on Day 28 post-first vaccine, while 13 subjects underwent additional blood sampling at least 2 weeks post-second vaccine.

\section{Study endpoints}

The primary endpoint was to assess humoral immunity against SARS-CoV-2-spike in thoracic cancer patients following COVID-19 mRNA BNT162b2 vaccine injection and booster dose. Some patients vaccinated outside our center received Moderna mRNA-1273 $(n=1)$ or Astra-Zeneca ChAdOx1 nCov-19 $(n=3)$ vaccines, being included herein.

Secondary endpoints were vaccination safety, clinical efficacy based on RT-PCRdocumented COVID-19 infection during the study, and hospitalization or death from

COVID-19. Phone safety consultations were scheduled every 3 weeks. Cell immunity to SARS-CoV-2-spike protein was evaluated using T-cell enzyme linked immunospot (ELISPOT), with lymphocyte subset counts, scheduled at Day 28 and from Day 42 post-first injection in 122 arbitrarily-designated patients.

\section{Laboratory analyses}

SARS-CoV-2 anti-N and anti-S antibody titers were determined using Abbott Architect SARS-CoV-2 IgG and IgG Quant II (Abbott, Maidenhead, UK) and 
medRxiv preprint doi: https://doi.org/10.1101/2021.08.12.21261806; this version posted August 13, 2021. The copyright holder for this preprint (which was not certified by peer review) is the author/funder, who has granted medRxiv a license to display the preprint in perpetuity. It is made available under a CC-BY-NC-ND 4.0 International license.

expressed as index (cut-off: 0.49) and arbitrary units (cut-off: $50 \mathrm{AU} / \mathrm{mL}$ ), respectively. Pseudo-neutralization assay was performed using iFlash-2019-nCoV Nab assay (YHLO, Shenzhen, China), which assesses antibody neutralizing capacity by competition with angiotensin-converting enzyme 2 (ACE2)-receptor for binding to anti-spike RBD (cut-off: 10AU/mL). This assay correlated with SARS-CoV-2 in vitro cell micro-neutralization (paper submitted for publication).

\section{ELISspot assay methods are in online supplement.}

\section{Statistical analysis}

All samples were de-identified and assigned an ID number, with the sampling date. Sample processing and data analyses were performed, with all study personal blinded to information concerning patients and samples. De-identified data were exported from Microsoft Excel Version 2013 for Windows (Microsoft Corporation, 2013) to IBM® SPSS® Statistics for Windows, Version 25.0 (IBM Corp., Armonk, N.Y., USA) for statistical analysis. Between-group comparisons were performed using Pearson's chi-squared or Fisher's exact tests for discrete variables, and Student's-T or Mann-Whitney U tests for continuous variables. Odds ratios (OR) and respective $95 \%$ confidence intervals $(95 \% \mathrm{Cl})$ were calculated using binary logistic regression. Hypothesis testing was two-tailed, with $p$ values $<0.05$ considered statistically significant. All assumptions required for logistic regression modeling were verified. Multivariable analysis was conducted using binary logistic regression using the Enter method, including variables exhibiting a significance threshold $p<0.20$ yielded by the univariable analysis.. 
medRxiv preprint doi: https://doi.org/10.1101/2021.08.12.21261806; this version posted August 13, 2021. The copyright holder for this preprint (which was not certified by peer review) is the author/funder, who has granted medRxiv a license to display the preprint in perpetuity. It is made available under a CC-BY-NC-ND 4.0 International license.

\section{Funding source}

The academic authors retained editorial control. The Assistance Publique-Hôpitaux de Paris funded the study, without participating to study design, data collection, data analysis, data interpretation, or report writing.

\section{RESULTS}

\section{Participant characteristics}

From January 20 to June 1, 2021, overall 325 thoracic cancer patients followed-up in thoracic oncology/surgery departments were proposed anti-SARS-CoV-2 vaccination with Pfizer BNT162b2 mRNA vaccine. Initially, only 36 (11\%) declined the proposal. Of these, 17 eventually accepted to be vaccinated; nine of whom were vaccinated outside of our center but participated to serological testing. Overall, 306 patients received their 28-day-spaced doses or underwent blood samplings between January 26 and May 17, 2021. Patient disposition is illustrated in suppl. Figure 1. Clinical follow-up was extended until July 28, 2021.

Patient clinical and demographic characteristics are provided in Table 1. Overall, 181 patients (59.2\%) were male and 285 (93.1\%) exhibited lung cancer with 260 (84.9\%) non-small cell lung carcinomas (NSCLCs) and 22 (7.2\%) small-cell lung carcinomas (SCLCs), while 13 (4.4\%) suffered from pleural malignant mesothelioma. Median age was 67 years IQR(58-74), with $41.2 \%$ older than 70 . Most patients $(57.2 \%)$ displayed late-stage disease, with 117 (38\%) cancer-diagnosed within <last 12 months. Last treatment received within three months prior-first vaccine was chemotherapy ( $n=74 ; 24.2 \%)$, given alone (51; 16.7\%), with concurrent thoracic radiotherapy $(n=2)$, or combined with $\mathrm{ICI}(21,6.9 \%)$, while 49 patients $(16 \%)$ received $\mathrm{ICI}$ alone, and $13.7 \%$ were treated with daily TKIs or maintenance bevacizumab. The 
medRxiv preprint doi: https://doi.org/10.1101/2021.08.12.21261806; this version posted August 13, 2021. The copyright holder for this preprint (which was not certified by peer review) is the author/funder, who has granted medRxiv a license to display the preprint in perpetuity.

It is made available under a CC-BY-NC-ND 4.0 International license.

last 141 patients $(30.7 \%)$ had not received systemic treatment within last three months. Overall, $37(12.1 \%)$ patients displayed chronic radiation pneumonitis following radio-chemotherapy of Stage III lung cancer. A thoracic surgery history was recorded in $89(29 \%)$ patients, six of whom (1.95\%) underwent pneumonectomy and $79(25.8 \%)$ lobectomy or sublobar resection. There were $20(6.5 \%)$ patients under oral corticosteroids for at least 3 weeks, for immune-mediated ICI toxicity, pain, brain metastasis, or severe chronic obstructive pulmonary disease. Overall, $59.5 \%$ patients were in complete or partial response at vaccination time, while $29.1 \%$ were only recently cancer-diagnosed or displayed progressive disease.

Total lymphocyte counts were available for 122 (39.9\%) patients on Day 28, with a median T-lymphocyte (CD3+) count at 1129/mm $\mathrm{mm}^{3} \mathrm{IQR}(742-1434)$, and median CD4+ T-cell count at 596/ $\mathrm{mm}^{3} \mathrm{IQR}(345-853)$.

\section{Humoral immune response}

Median follow-up was 141 days IQR(134-183). Overall, 283 (92.5\%) patients underwent serological testing at Day 28 post-first injection and received a second vaccine on that booster day. At Day 28, At Day 28, 248 samples from patients free of prior SARS-CoV-2 infection or with anti-N negative IgG at D0 or D28 $(n=265)$ were available. Median anti-S IgG IgG titer was 149.7 AU/mL IQR(21.9 - 436.1).

In patients without symptomatic or asymptomatic COVID-19 (thus excluding twentytwo patients, 17 with prior COVID-19 history, 3 with PCR-proved COVID-19 post-1st dose, and 2 with anti-N $\lg$ detected at D0) history, a striking increase in antibody titers occurred between Day 0 (137 patients with available serology) and Day 28 (248 patients with available serology) post-first vaccine (Figure 1A). 
medRxiv preprint doi: https://doi.org/10.1101/2021.08.12.21261806; this version posted August 13, 2021. The copyright holder for this preprint (which was not certified by peer review) is the author/funder, who has granted medRxiv a license to display the preprint in perpetuity.

It is made available under a CC-BY-NC-ND 4.0 International license .

Not all antibodies detected are able to efficiently neutralize the virus by impairing its binding to the ACE2 receptor expressed by respiratory cells. Neutralizing antibodies constitute a variable part of the anti-spike antibodies. The neutralization activity was measured using a pseudo-neutralization assay, assessing neutralizing antibody capacity via competition with ACE2-receptor for binding to anti-spike RBD. Suppl. Figure 2 depicts the correlation between anti-S $\lg \log _{10}$ titers and anti-spike RBD pseudo-neutralization $\log _{10}$ titers. A strong correlation was observed from anti-S IgG titer of $300 \mathrm{AU} / \mathrm{mL}$ (Spearman's test, rho=0.92, $p<0.0001$ ), supporting the neutralizing effect of serum anti-S IgG levels levels exceeding such cut-off.

At Day 28, 91 patients (32.3\%) displayed no anti-S IgG (<50 AU/mL), while 165 patients $(58.5 \%)$ exhibited only low titers ( $\leq 300 \mathrm{AU} / \mathrm{mL})$.

By comparison, the median value of 18 healthy controls was $913 \mathrm{AU} / \mathrm{mL} \operatorname{IQR}(438,3$ 1859.3), antibody titer distribution of healthy controls significantly differing from that of patients treated using chemotherapy ( $p<0.0001$, Mann-Whitney), immunotherapy ( $p<0.0001$, Mann-Whitney), targeted therapy or bevacizumab $(p=0.043$, MannWhitney), or those without systemic therapy <last three months ( $p<0.0001$, MannWhitney) (Figure 1B). No significant differences in serum anti-spike antibody titers were seen between chemotherapy- and immunotherapy-treated patients $(p=0.11)$.

The second booster dose was not administered to 24 patients due to cancer-related general condition alteration $(n=2)$, mild symptomatic PCR-proven COVID-19 infection post-first vaccine $(n=3)$, history of symptomatic COVID-19 before vaccination supported by anti-N IgG detection $(\mathbf{n = 1 7})$, and totally asymptomatic COVID-19as reflected again by anti-N IgG detection $(n=2)$.

Serological data were available for 269 (88\%) patients at Day 42, two-to-nine weeks 
medRxiv preprint doi: https://doi.org/10.1101/2021.08.12.21261806; this version posted August 13, 2021. The copyright holder for this preprint (which was not certified by peer review) is the author/funder, who has granted medRxiv a license to display the preprint in perpetuity.

It is made available under a CC-BY-NC-ND 4.0 International license .

post-second vaccine (median time interval: 52 days IQR(45-69). Of the 306 patients, 37 could not undergo late serological control due to altered general condition $(n=4)$, cancer-related death $(n=9)$, patients refusal $(n=5)$, whereas 19 patients exhibited COVID-19 at any time, with late serological control deemed unnecessary by referent physicians.

Among patients free of prior SARS-CoV-2 infection or with anti-N negative IgG at D0 and D28 ( $n=265), 248$ samples were available at D42 ( $\geq 14$ days post-second dose) with median serum anti-S IgG titer at $4725 \mathrm{AU} / \mathrm{mL}$ IQR(1066 - 13698), $300 \mathrm{AU} / \mathrm{mL}$ corresponding to $12.5^{\text {th }}$ percentile.

Two-to-nine weeks post-second vaccine, an overall increase in serum anti-S IgG titers was noted (Figure 1C) with a mean 1.4-to-2-fold increase in the $\log _{10}$ anti-spike IgG concentrations. However, 17 patients (6.3\%) still exhibited negative serological testing, while 34 (11\%) displayed IgG concentrations $\leq 300 \mathrm{AU} / \mathrm{mL}$, with 65 patients (24.1\%) exhibiting antibody titers below the first quartile value of $1066 \mathrm{UA} / \mathrm{mL}$.

The median serum anti-S IgG concentration in 13 healthy controls, within a median 57-day interval post-second vaccine, was 10594 AU/mL IQR(8350-14836). The titer distribution significantly differed from that observed in patients treated using chemotherapy ( $p=0.0003$, Mann-Whitney), immunotherapy $(p=0.013$, MannWhitney), oral targeted therapy or bevacizumab ( $p=0.02$, Mann-Whitney), or those without systemic therapy <last three months ( $p=0.001$, Mann-Whitney) (Fig. 1C).

Considering the 231 patients with available data at both points, the anti-S IgG titers significantly rose between Day 28 (first dose) and Day 42 (second dose), irrespective of systemic treatments received (Figure 2), with higher titers observed in previously COVID-19-infected patients ( $n=31$ ) (suppl. Figure 3). In patients for whom serology was available at Day 28 post-first (sole) vaccine, an increase by 2 logs in anti-S IgG 
medRxiv preprint doi: https://doi.org/10.1101/2021.08.12.21261806; this version posted August 13, 2021. The copyright holder for this preprint (which was not certified by peer review) is the author/funder, who has granted medRxiv a license to display the preprint in perpetuity.

It is made available under a CC-BY-NC-ND 4.0 International license .

antibodies was recorded, these antibodies remaining high in 14 patients on later samplings.

During the 6-month follow-up from late January to July 2021 , seven patients $(2.3 \%)$ experienced mildly symptomatic PCR-proven COVID-19 symptoms. In four, these symptoms respectively occurred at Days 4, 6, 12, and 20 post-first vaccine, and in the remaining three, respectively, at Days 33,35 , and 42 post-second vaccine. Only one thymic carcinoma patient (serum anti-S lgG titers at $300.4 \mathrm{AU} / \mathrm{mL}$ two days before positive SARS-CoV-2 PCR testing) was hospitalized, due to his frail condition, yet without requiring oxygen supply. He was discharged a week later.

\section{Safety}

No anaphylaxis reaction occurred among the 306 patients, with 587 vaccine doses administered. Safety data were available for 278 patients (90.1\%), without significant safety concerns. One-third of patients $(n=98)$ did not report symptoms post-first injection. Reported undesirable effects were transitory pain, injection-site swelling, or Grade 1 injection-site erythema, lasting $<24$ hours. More frequent undesirable effects of mild intensity were reported post-second vaccination in two-thirds of patients ( $n=201)$, including injection-site erythema, pain, local injection-site swelling, mild fever $\left(<38.5^{\circ} \mathrm{C}\right)$, all lasting $<36$ hours. Flu-like symptoms, chills, and fatigue lasting $<48$ hours were reported in $25(8 \%)$ cases. In one patient, a spectacular Grade 2 urticarial reaction occurred, resolving under oral antihistamines <three days of booster dosing. Another patient reported a large Grade 2 local reaction manifesting within 24 hours post-second injection, as large annular erythema plaques, with pain, fatigue, and mild fever $\left(38^{\circ} \mathrm{C}\right)$, with spontaneous resolution within eight days. No vaccine-related death occurred. 


\section{Predictors of lack of immunization}

We analyzed the correlation between serological titers using different cut-points $(\leq 50$ $\mathrm{AU} / \mathrm{mL} ; \leq 300 \mathrm{AU} / \mathrm{mL}$ ) and the main clinical, demographic, and biological variables (suppl. Table 1A, B, C, D). At Day 28, age ( $p<0.0001$, suppl. Fig. 4A), male gender $(p=0.05)$, chemotherapy-based treatment <three last months $(p=0.004)$, immunotherapy as single-therapy <three last months $(p=0.01)$, long-term corticosteroid treatment $(p=0.01)$, and lack of disease control $(p=0.03)$, were significantly associated with negative serological testing $\leq 50 \mathrm{AU} / \mathrm{mL}$ in univariable analyses (suppl. Table 1A). Conversely, each 100 units/mm3 increase in Day 28 Tlymphocyte $(C D 3+)$ counts $(p=0.008)$, and Day 28 CD4+ T-cell counts $(p=0.002$, suppl. Fig. 4B), were associated with higher seroconversion probability $(n=122)$. In 111 patients for whom these analyses were performed, Day 28 interferon-y specific T-cell response to SARS-CO-2-spike measured by ELISPOT assay was significantly associated with higher seroconversion probability at Day $28(\mathrm{OR}=0.968 ; 95 \% \mathrm{Cl}$ : 0.941-0.995, $p=0.021)$.

Considering variables exhibiting a $p=0.2$ value in univariable analyses, except for the immunological data ( $\mathrm{n}=122$ or 111$)$, multivariable logistic regression analyses (suppl.

Table 1A) confirmed that age (adjusted $\mathrm{OR}=1.05 ; 95 \% \mathrm{Cl}: 1.02-1.08, \mathrm{p}=0.0001$ ), with a $5 \%$ increase in non-immunization risk at Day 28 for each year, long-term corticosteroids (adjusted OR=3.26; 95\%Cl:1.1-9.6, $\mathrm{p}=0.033$ ), and chemotherapy as last treatment $<$ three last months (adjusted $\mathrm{OR}=3.0 ; 95 \% \mathrm{Cl}: 1.05-8.4, \mathrm{p}=0.041$ ) were independently associated with antibody titers $\leq 50 \mathrm{AU} / \mathrm{mL}$ at Day 28 . 
medRxiv preprint doi: https://doi.org/10.1101/2021.08.12.21261806; this version posted August 13, 2021. The copyright holder for this preprint (which was not certified by peer review) is the author/funder, who has granted medRxiv a license to display the preprint in perpetuity.

It is made available under a CC-BY-NC-ND 4.0 International license .

Considering Day 28 cut-off at $\leq 300 \mathrm{AU} / \mathrm{mL}$ (suppl. Table 1B), age $(p<0.0001$, suppl. Fig. $4 C)$, male gender $(p=0.019)$, chemotherapy $(p=0.007)$, or immunotherapy $(p=0.037)$ as last treatment were significantly associated with anti-S IgG titers $\leq 300$ AU/mL. Although T-lymphocyte and CD4+ T-cell counts failed to predict seroconversion at this cut-off, Day 28 interferon-y specific T-cell responses to SARSCO-2-spike (ELISPOT assay; $n=90$ ), was highly predictive of anti-S IgG titers over $300 \mathrm{AU} / \mathrm{mL}(\mathrm{OR}=0.956 ; 95 \%$ IC: $0.935-0.978, \mathrm{p}<0.0001)$ in 111 patients with available results.

In multivariable analyses, only age, (adjusted $\mathrm{OR}=1.05,95 \% \mathrm{Cl}: 1.02-1.7, \mathrm{p}<0.0001)$ and chemotherapy as last treatment received (adjusted OR=3.07; 95\% $\mathrm{Cl}: 1.36-6.94$, $p=0.048$ ) were independently associated with Day 28 anti-S IgG titers $\leq 300 \mathrm{AU} / \mathrm{mL}$.

Considering Day 42 cut-off at $\leq 50 \mathrm{AU} / \mathrm{mL}$ (post-second vaccination), the variables significantly associated with negative serology risk included age $(p=0.013)$, lack of disease control $(p=0.015)$, chronic corticosteroids $(p=0.007)$, and chemotherapy as last treatment received ( $p=0.021$ ) (suppl. Table 1C). Conversely, in 74 patients with available data, each 100 units/mm3 increase in Day 42 T-cell $(O R=0.60$; 95\%Cl:0.40-0.89, $\mathrm{p}=0.012$ ) or $\mathrm{CD} 4+\mathrm{T}$-cell counts $(\mathrm{OR}=0.15 ; 95 \% \mathrm{Cl}: 0.35-0.63$, $\mathrm{p}=0.009$ ) was associated with a higher seroconversion probability. In multivariable analyses, age (adjusted $\mathrm{OR}=1.09 ; 95 \% \mathrm{Cl}: 1.03-1.15, \mathrm{p}=0.004$ ), chemotherapy as last treatment received (adjusted $\mathrm{OR}=6.60 ; 95 \% \mathrm{Cl}: 1.05-41.62, \mathrm{p}=0.045$ ), and long-term corticosteroids (adjusted OR=6.22; 95\%Cl:1.41-27.43, $\mathrm{p}=0.016$ ), were significantly associated with negative Day 42 serology ( $\leq 50 \mathrm{AU} / \mathrm{mL})$.

Considering Day 42 cut-off at $\leq 300 \mathrm{AU} / \mathrm{mL}$ (suppl. Table 1D), age $(p=0.028)$ metastatic disease extent $(p=0.014)$, chemotherapy <three last months $(p=0.004)$ 
medRxiv preprint doi: https://doi.org/10.1101/2021.08.12.21261806; this version posted August 13, 2021. The copyright holder for this preprint (which was not certified by peer review) is the author/funder, who has granted medRxiv a license to display the preprint in perpetuity.

It is made available under a CC-BY-NC-ND 4.0 International license.

long-term corticosteroids $(p<0.00001)$, and lack of disease control $(p=0.010)$ were associated with lower immunization probability. Conversely, cancer duration was associated with a higher Day 42 sero-conversion probability $>300 \mathrm{AU} / \mathrm{mL}(p=0.01)$. In 74 patients with immunological data, each 100 units $/ \mathrm{mm}^{3}$ increase in Day 42 T-cell $(\mathrm{OR}=0.73 ; 95 \% \mathrm{Cl}: 0.59-0.90, \mathrm{p}=0.003)$ or $\mathrm{CD} 4+\mathrm{T}$-cell counts $(\mathrm{OR}=0.53 ; 95 \% \mathrm{Cl}: 0.35$ 0.82, $p=0.005$ ) was associated with higher seroconversion probability. Only age (adjusted $\mathrm{OR}=1.07 ; 95 \% \mathrm{Cl}: 1.02-1.11, \mathrm{p}=0.002$ ), chemotherapy as last treatment received (adjusted $\mathrm{OR}=3.14 ; \quad 95 \% \mathrm{Cl}: 1.08-9.13, \quad \mathrm{p}=0.036$ ), and long-term corticosteroids (adjusted $\quad \mathrm{OR}=6.2, \quad 95 \% \mathrm{Cl}: 1.4-27.4, \quad \mathrm{p}=0.016) \quad$ independently influenced the probability of low response (anti-SARS-COV-2-spike IgG titers $\leq 300$ $\mathrm{AU} / \mathrm{mL}$ ) in multivariable analyses, diminishing the probability of a reliable protection against SARS-CoV-2 infection.

\section{Third vaccine dose}

Serial serological tests were performed in ten patients exhibiting low antibody titers post-vaccine boosting ( $\leq 300 \mathrm{AU} / \mathrm{mL})$. In seven, the antibody titers decreased over time $(n=6)$ or remained stable $(n=1)$, within a $13-52$ day period, whereas the three others displayed a slight increase over $300 \mathrm{AU} / \mathrm{mL}$, within 59 days post-second dose. Two patients still presented $<1066 \mathrm{AU} / \mathrm{mL}, 53$ and 47 days post-booster dose, remaining $<25^{\text {th }}$ percentile. Seven of these patients were still receiving chemotherapy-based treatment $(n=5)$ or corticosteroids $(n=2)$, with three receiving neither chemotherapy nor corticosteroids.

At Day 42, 30 patients exhibiting anti-S IgG titers $\leq 300 \mathrm{AU} / \mathrm{mL}$ were proposed a third vaccine, from Day 28 post-second shot. Of these, two experienced cancer-related condition deterioration; therefore, they underwent no serology control post-third 
medRxiv preprint doi: https://doi.org/10.1101/2021.08.12.21261806; this version posted August 13, 2021. The copyright holder for this preprint (which was not certified by peer review) is the author/funder, who has granted medRxiv a license to display the preprint in perpetuity.

It is made available under a CC-BY-NC-ND 4.0 International license .

injection. A serology assay was available beyond Day 21 post-third injection in 26/30 remaining (results still awaited for two). At the time of analysis, none of these patients displayed symptomatic COVID-19. In 26 (86.7\%) patients with serological tests available at Day 28 post-third shot (Figure 3A), 19 (73\%) demonstrated a dramatic rise in anti-S IgG titers, exceeding $3500 \mathrm{AU} / \mathrm{mL}$, four (15.4\%) displayed a moderate increase beyond $300 \mathrm{AU} / \mathrm{mL}$ cut-point, yet <1000 AU/mL (Figure 3B). Therefore, 88.5\% exhibited sero-conversion. In all, persistent negative anti-N IgG were found, excluding any recent SARS-CoV-2 infection. Among these, three had been receiving corticosteroids for several weeks, which were continued at third vaccination. Only three patients did not respond to third vaccination, all being older than 65 years, being either totally negative $(n=2,<50 / A U / m L)$ or exhibiting low anti-spike antibodies. Among them was patient (still $<50 \mathrm{AU} / \mathrm{mL}$ post-second booster), on chronic myelomonocytic leukemia Type 2, with complete molecular response. The two other patients, respectively displaying 47 and $157 \mathrm{AU} / \mathrm{mL}$, were treated using either chemo-immunotherapy or $\mathrm{ICI}$ alone. These two latter patients, also suffered from hematological conditions (hypogammaglobulinemia, monoclonal IgG peak), possibly explaining their poor immunization.

\section{DISCUSSION}

COVID-19 vaccines were made available in France in January 2021. Nothing was known on COVID-19 vaccination efficacy in patients with poor immune conditions, including metastatic lung cancer patients, especially those under systemic corticosteroids or cytotoxic chemotherapy. Though lung cancer patients were reported at high COVID-19-related mortality risk in published series, lethality systematically exceeding $30 \%$ of infected patients ${ }^{1,3,28}$, we observed only seven mild 
medRxiv preprint doi: https://doi.org/10.1101/2021.08.12.21261806; this version posted August 13, 2021. The copyright holder for this preprint (which was not certified by peer review) is the author/funder, who has granted medRxiv a license to display the preprint in perpetuity.

It is made available under a CC-BY-NC-ND 4.0 International license .

COVID-19 cases among our 306 vaccinated patients (2.3\%). Such observation strongly supports the efficacy of mRNA COVID-19 vaccines used in $98.4 \%$ of our population. A possible limitation to such outcome is the decrease in SARS-CoV-2 virus circulation <0.79 in France by mid-May 2021, versus 1.2 or 1.3 in late January 2021. However, a dramatic rise in infections occurred early July, resulting in $>20,000$ new daily cases. The patient acceptation rate of systematic vaccination was in line with previous reports, with only $11 \%$ initial refusals ${ }^{29}$. Reactogenicity was weak, without short-term serious adverse effects in this real-life setting. We did not observe specific safety concerns in ICl-treated patients, especially regarding immune-related side-effects, as reported by Israeli teams ${ }^{30}$. Moreover, our study emphasized that sero-conversion monitoring could be useful in immuno-suppressed patients. In this population, the first vaccine efficacy was much lower than that reported in vaccine registration trials, with one-third of patients displaying negative serological testing $(\leq 50 \mathrm{AU} / \mathrm{mL})$ at Day 28 , whereas three-quarters exhibited $<25^{\text {th }}$ percentile serological titer distribution. These data are in line with prospective studies involving a mixed population with solid cancers and hematological malignancies ${ }^{31,32}$. Although there has been no clear cut-off for antibody titers predicting protection against severe COVID-19, a $300 \mathrm{AU} / \mathrm{mL}$ cut-off was shown to well correlate with the pseudoneutralization assay, as a readout for anti-viral efficacy. We thus selected this value as protection cut-off against SARS-CoV-2 infection in our patients ${ }^{33}$. Let us keep in mind that the recently described delta strain, which currently represents more than $90 \%$ of sequenced viral isolates in France $^{34}$, was reported to be $40-80 \%$ more transmissible than the alpha strain ${ }^{35,36}$, its viral burden being 1000 fold higher than other strains ${ }^{37}$. It is thus crucial to define serological correlates confirming the protection of immuno-compromised patients. 
medRxiv preprint doi: https://doi.org/10.1101/2021.08.12.21261806; this version posted August 13, 2021. The copyright holder for this preprint (which was not certified by peer review) is the author/funder, who has granted medRxiv a license to display the preprint in perpetuity.

It is made available under a CC-BY-NC-ND 4.0 International license.

With this in mind, our study provided strong evidence for keeping the initially established intervals between two vaccine shots for cancer patients. These patients displayed a delay in their immunization process, with lower levels of protective circulating vaccination-induced antibodies versus healthy vaccinated controls. Conversely, a reassuring observation has been the booster injection's remarkable efficacy, with only $6.0 \%$ of thoracic cancer patients still displaying negative serology at Day 42, whereas only $\%$ exhibited antibody titers $\leq 300 \mathrm{AU} / \mathrm{mL}$. The two characteristics independently associated with poor immunization, irrespective the cutpoint chosen, were age and long-term corticosteroids. Concerning age, a lower immunization rate was identified in octogenarians, along with a $5 \%$ decreased probability per year to reach protective immunization. Regarding long-term corticosteroids, the lower immunization may probably be explained by either lower total T-cell and CD4+ T-lymphocyte counts or T-cell specific responses to spike protein. The adverse impact of age on the ability to induce vaccine-related protective humoral responses was already highlighted in a study involving octogenarians ${ }^{38,39}$. While clearly delaying the immunization process as previously reported ${ }^{31,40,41}$, cytotoxic chemotherapy was associated with higher low-immunization rates at Day 42, as well.

As herein shown, a third vaccine could contribute to appropriate sero-protection in patients still poorly immunized post-two vaccines. Overall, 92\% of patients were shown to benefit from a third shot, reflected by substantial increases in anti-S IgG antibodies, with only very few patients left without sufficient protection. A limitation to this observation is the group's small sample size. Such outcome must be confirmed in larger-scale studies involving solid cancer patients. Notably, a third vaccine dose is 
medRxiv preprint doi: https://doi.org/10.1101/2021.08.12.21261806; this version posted August 13, 2021. The copyright holder for this preprint (which was not certified by peer review) is the author/funder, who has granted medRxiv a license to display the preprint in perpetuity. It is made available under a CC-BY-NC-ND 4.0 International license.

still being debated in patients with hematological malignancies or solid organ transplantation ${ }^{42-47}$. This latter statement is supported by the fact that three of our patients with negative serology post-third vaccine were, indeed, suffering from underlying hematological conditions. Consequently, patients with lymphocyte function defects due to lymphoid cancers or lymphocyte-depleting treatments ${ }^{44}$ may exhibit lower benefits from a third vaccination. 
medRxiv preprint doi: https://doi.org/10.1101/2021.08.12.21261806; this version posted August 13, 2021. The copyright holder for this preprint (which was not certified by peer review) is the author/funder, who has granted medRxiv a license to display the preprint in perpetuity. It is made available under a CC-BY-NC-ND 4.0 International license.

List of supplementary material:

Supplemental Figure 1: Patients disposition

Supplemental Figure 2: Correlation between anti-SARS-Cov-2-spike IgG antibody titers and -spike RBD-pseudo-neutralization titers

Supplemental Figure 3: Anti-SARS-Cov-2-spike lgG antibody titers, at Day 0, Day 28, and Day 42, (respectively $n=26, n=31$, and $n=14$ ) in 34 patients with previous COVID-19- history or positive antiSARS-Cov-2-Nucleocapsid IgG serology.

Supplemental Figure $4 \mathrm{~A}, 4 \mathrm{~B} \& 4 \mathrm{C}$ :

4A: Distribution of patient ages according to Day 28 anti-S IgG antibody titers, above or below $50 \mathrm{AU} / \mathrm{mL}$

4B: Distribution of patients' T-lymphocyte counts according to Day 28 anti-S IgG antibody titers, above or below $50 \mathrm{AU} / \mathrm{mL}$

4C: Distribution of patient ages according to Day 28 anti-S IgG antibody titers, above or below $300 \mathrm{AU} / \mathrm{mL}$

Supplemental Immunology methods

Supplemental Table 1A: predictors of non-immunization (anti-S IgG antibodies at 50 $\mathrm{AU} / \mathrm{mL}$ cut-off) at D28

Supplemental Table 1B: predictors of non-immunization (anti-S IgG antibodies at 300 $\mathrm{AU} / \mathrm{mL}$ cut-off) at D28

Supplemental Table $1 \mathrm{C}$ : predictors of non-immunization (anti-S IgG antibodies at 50 $\mathrm{AU} / \mathrm{mL}$ cut-off) at $\mathrm{D} 42$

Supplemental Table 1D: predictors of non-immunization (anti-S lgG antibodies at 300 $\mathrm{AU} / \mathrm{mL}$ cut-off) at D28 
medRxiv preprint doi: https://doi.org/10.1101/2021.08.12.21261806; this version posted August 13, 2021. The copyright holder for this preprint (which was not certified by peer review) is the author/funder, who has granted medRxiv a license to display the preprint in perpetuity.

It is made available under a CC-BY-NC-ND 4.0 International license .

\section{Figure Legends}

Figure 1: Serological response to COVID-19 vaccine BNT162b2 in COVID-free patients

(A) Anti-SARS-CoV-2-spike (anti-S) IgG antibody titers at Day 0 in 137 patients without previous history of COVID-19; at Day 28 after one vaccine dose injection in 248 patients without previous history of COVID-19; beyond Day 42 in 248 patients without previous history of COVID-19; beyond Day 21 after third vaccine dose in 30 patients with available results. Large horizontal bars represent the median value, with short bars showing the first (lower) and third (upper) quartiles values. The MannWhiney test was applied for statistical comparison.

(B) Anti-S IgG antibody titers at Day 28 after the first vaccine dose, according to the systemic treatment received within the previous three months: chemotherapy, including chemo-immunotherapy $(n=62)$, immunotherapy alone $(n=41)$, oral tyrosine kinase inhibitor (TKI) or bevacizumab single-agent therapy $(n=34)$, or without systemic treatment $(n=111)$. Anti-S IgG antibody titers at Day 28 in 18 healthy controls are shown. Large horizontal bars represent the median value, with short bars showing the first (lower) and third (upper) quartiles values. The Mann-Whiney test was applied for statistical comparison.

(C) Anti-S IgG antibody titers at Day 42 or beyond after the first vaccine dose, according to the systemic treatment received within the previous three months: chemotherapy, including chemo-immunotherapy $(n=58)$, immunotherapy alone $(n=41)$, oral TKI or bevacizumab single-agent $(n=36)$, or without systemic treatment $(n=113)$. Anti-SARS-CoV-2-spike IgG antibody titers at Day 42 in 13 healthy controls were available. Large horizontal bars represent the median value, with short bars showing the first (lower) and third (upper) quartiles values. The Mann-Whiney test was applied for statistical comparison.

Figure 2: Anti-SARS-Cov-2-spike $\lg$ antibody titers at Day 28 and Day 42 according to the different systemic treatments received.

The horizontal dashed lines along the $x$ axes indicate the limit of detection (positivity cut-off) provided by the manufacturer $\left(\log _{10} 50 \mathrm{AU} / \mathrm{mL}\right)$. A nonparametric two-tailed pair-wise comparison was performed using the Wilcoxon matched-pairs signed-rank 
medRxiv preprint doi: https://doi.org/10.1101/2021.08.12.21261806; this version posted August 13, 2021. The copyright holder for this preprint (which was not certified by peer review) is the author/funder, who has granted medRxiv a license to display the preprint in perpetuity.

test.

\section{Figure 3:}

Figure 3A: Evolution from Day 0 of anti-SARS-Cov-2-spike IgG antibody titers after a third vaccine dose injection in 26 patients with titers below $300 \mathrm{AU} / \mathrm{mL}$ at post-second dose sampling. The lower dashed line along the $x$ axe indicates the limit of detection (positivity cut-off) provided by the manufacturer $\left(\log _{10} 50 \mathrm{AU} / \mathrm{mL}\right)$. The upper dashed line along the $x$ axe indicates $\log _{10} 300 \mathrm{AU} / \mathrm{mL}$ cut-off. Statistical comparison used Mann-Whiney test.

Figure 3B: Comparison of anti-SARS-Cov-2-spike IgG antibody titers at Day 42 with titers post-third vaccine dose in 26 patients, and with Day 42 titers of 222 patients who received two doses. Statistical comparison used Mann-Whiney test.

Suppl. Figure 1: Patients disposition

Suppl. Figure 2: Correlation between anti-SARS-Cov-2-spike IgG antibody titers $\left(\log _{10}\right.$ Arbitrary Unit/mL), $x$ axis, and -spike RBD-pseudo-neutralization titers $\left(\log _{10}\right.$ $\mathrm{AU} / \mathrm{mL}$ ), y axis. Vertical dashed lines correspond to the $50 \mathrm{AU} / \mathrm{mL}$ (cut-point for positivity according to the manufacturer) and $300 \mathrm{AU} / \mathrm{mL}$ anti-SARS-Cov-2-spike IgG antibody $\log _{10}$ titers. The two assays showed an excellent correlation (Spearman's test, rho $=0.92, p<0.0001)$.

Suppl. Figure 3: Anti-SARS-Cov-2-spike IgG antibody titers, at Day 0, Day 28, and Day 42 , (respectively $n=26, n=31$, and $n=14$ ) in 34 patients with previous COVID-19history or positive anti-SARS-Cov-2-Nucleocapsid IgG serology. The horizontal dashed line along the $x$ axe indicates the limit of detection (positivity cut-off) provided by the manufacturer $\left(\log _{10} 50 \mathrm{AU} / \mathrm{mL}\right)$. Statistical comparison used Mann-Whiney test.

\section{Supp. Figure 4A, B \& C:}

Suppl. Figure 4A: Distribution of patient ages according to Day 28 anti-S IgG antibody titers, above or below $50 \mathrm{AU} / \mathrm{mL}$. Statistical comparison used Mann-Whiney $\mathrm{U}$ test. 
medRxiv preprint doi: https://doi.org/10.1101/2021.08.12.21261806; this version posted August 13, 2021. The copyright holder for this preprint (which was not certified by peer review) is the author/funder, who has granted medRxiv a license to display the preprint in perpetuity. It is made available under a CC-BY-NC-ND 4.0 International license.

Suppl. Figure 4B: Distribution of patients' T-lymphocyte counts according to Day 28 anti-S IgG antibody titers, above or below $50 \mathrm{AU} / \mathrm{mL}$. Statistical comparison used Mann-Whiney U test.

Suppl. Figure 4C: Distribution of patient ages according to Day 28 anti-S $\lg G$ antibody titers, above or below $300 \mathrm{UA} / \mathrm{mL}$. Statistical comparison used MannWhiney $U$ test. 
medRxiv preprint doi: https://doi.org/10.1101/2021.08.12.21261806; this version posted August 13, 2021. The copyright holder for this preprint (which was not certified by peer review) is the author/funder, who has granted medRxiv a license to display the preprint in perpetuity.

\section{REFERENCES}

1. Lièvre A, Turpin A, Ray-Coquard I, et al. Risk factors for Coronavirus Disease 2019 (COVID-19) severity and mortality among solid cancer patients and impact of the disease on anticancer treatment: A French nationwide cohort study (GCO-002 CACOVID19). Eur J Cancer 2020; $141: 62-81$.

2. Whisenant J, Trama A, Torri V, et al. TERAVOLT: Thoracic Cancers International COVID-19 Collaboration. Cancer Cell. 2020; 37 742-5.

3. Garassino M, Whisenant J, Huang L, et al. COVID-19 in patients with thoracic malignancies (TERAVOLT): first results of an international, registry-based, cohort study. Lancet Oncol 2020 21: 914-22.

4. Zhang L, Zhu F, Xie L, et al. Clinical characteristics of COVID-19-infected cancer patients: a retrospective case study in three hospitals within Wuhan, China. Ann Oncol 2020; 31: 894-901.

5. Dai M, Liu D, Liu M, et al. Patients with Cancer Appear More Vulnerable to SARSCoV-2: A Multicenter Study during the COVID-19 Outbreak. Cancer Discov 2020; 10: 78391.

6. Yang K, Sheng Y, Huang C, et al. Clinical characteristics, outcomes, and risk factors for mortality in patients with cancer and COVID-19 in Hubei, China: a multicentre, retrospective, cohort study. Lancet Oncol 2020; 21: 904-13.

7. Onder G, Rezza G and Brusaferro S. Case-Fatality Rate and Characteristics of Patients Dying in Relation to COVID-19 in Italy. JAMA 2020; 323: 1775-6. .

8. Levin A, Hanage W, Owusu-Boaitey N, Cochran K, Walsh S and Meyerowitz-Katz G. Assessing the age specificity of infection fatality rates for COVID-19: systematic review, meta-analysis, and public policy implications. Eur J Epidemiol 2020; 35: 1123-38. 9. Meyerowitz-Katz G and Merone L. A systematic review and meta-analysis of published research data on COVID-19 infection fatality rates. Int J Infect Dis 2020; 101: 138-48.

10. Mi Y, Huang T, Zhang J, et al. Estimating the instant case fatality rate of COVID-19 in China. Int J Infect Dis 2020 97: 1-6.

11. Hawkins R, Charles E and Mehaffey J. Socio-economic status and COVID-19related cases and fatalities. Public Health. 2020; 189: 29-134.

12. Rondy M, Larrauri A, Casado I, et al. 2015/16 seasonal vaccine effectiveness against hospitalisation with influenza $\mathrm{A}(\mathrm{H} 1 \mathrm{~N} 1) \mathrm{pdm} 09$ and B among elderly people in Europe: results from the I-MOVE+ project. Euro Surveill. 2017; 22: 30580. .

13. Hottinger A, George A-C, Bel M, et al. A Prospective Study of the Factors Shaping Antibody Responses to the AS03-Adjuvanted Influenza A/H1N1 Vaccine in Cancer Outpatients. The Oncologist. 2012; 17: 436-45.

14. Beck C, McKenzie B, Hashim A, Harris R and University of Nottingham Influenza and the ImmunoCompromised (UNIIC) Study Group N-V-T, JS. Influenza vaccination for immunocompromised patients: systematic review and meta-analysis by etiology. J Infect Dis. 2012 206: 1250-9..

15. Bersanelli M, Giannarelli D, De Giorgi U, et al. INfluenza Vaccine Indication During therapy with Immune checkpoint inhibitors: a multicenter prospective observational study (INVIDIa-2). J Immunother Cancer. 2021; 9: e002619.

16. Polack F, Thomas S, Kitchin N, et al. Safety and Efficacy of the BNT162b2 mRNA Covid-19 Vaccine. . New Engl J Med. 2020; 383: 2603-15.

17. Jackson L, Anderson E, Rouphael N, et al. An mRNA Vaccine against SARS-CoV-2 -Preliminary Report. N Engl J Med 2020; 383: 1920-31. 
medRxiv preprint doi: https://doi.org/10.1101/2021.08.12.21261806; this version posted August 13, 2021. The copyright holder for this preprint (which was not certified by peer review) is the author/funder, who has granted medRxiv a license to display the preprint in perpetuity.

18. Baden L, El Sahly H, Essin B, et al. Efficacy and Safety of the mRNA-1273 SARSCoV-2 Vaccine. New Engl J Med. 2020; 384: 403-16.

19. Sadoff J, Gray G, Vandebosch A, et al. Safety and Efficacy of Single-Dose Ad26.COV2.S Vaccine against Covid-19. N Engl J Med 2021 384: 2187-201.

20. Voysey M, Clemens S, Madhi S, et al. Safety and efficacy of the ChAdOx1 nCoV-19 vaccine (AZD1222) against SARS-CoV-2: an interim analysis of four randomised controlled trials in Brazil, South Africa, and the UK. Lancet 2021; 397: 99-111.

21. Voysey M, Costa Clemens S, Madhi S, et al. Single-dose administration and the influence of the timing of the booster dose on immunogenicity and efficacy of ChAdOx1 nCoV-19 (AZD1222) vaccine: a pooled analysis of four randomised trials. Lancet 2021 397: 881-91.

22. Milman 0, Yelin I, Aharony N, et al. Community-level evidence for SARS-CoV-2 vaccine protection of unvaccinated individuals. Nat Med. 2021; Jun. 10. DOI: 10.1038/s41591-021-01407-5.

23. Vasileiou E, Simpson C, Shi T, et al. Interim findings from first-dose mass COVID19 vaccination roll-out and COVID-19 hospital admissions in Scotland: a national prospective cohort study. Lancet. 2021; 397: 1646-57.

24. Widge A, Rouphael N, Jackson L, et al. Durability of Responses after SARS-CoV-2 mRNA-1273 Vaccination. New Engl J Med. 2020; 384: 80-2.

25. Robertson J, Sewell H and Stewart M. Delayed second dose of the BNT162b2 vaccine: innovation or misguided conjecture? Lancet. 2021; 397 879-80.

26. Kadire S, Wachter R and N L. Delayed Second Dose versus Standard Regimen for Covid-19 Vaccination. New Engl J Med. 2021; 384: e28. .

27. Castells $\mathrm{M}$ and Phillips E. Maintaining Safety with SARS-CoV-2 Vaccines. New Engl J Med. 2021; 384: 643-9.

28. Luo J, Rizvi H, Preeshagul I, et al. COVID-19 in patients with lung cancer. Ann Oncol. 2020; 31: 1386-96.

29. Di Noia V, Renna D, Barberi V, et al. The first report on coronavirus disease 2019 (COVID-19) vaccine refusal by patients with solid cancer in Italy: Early data from a single-institute survey. Eur J Cancer. 2021; $153260 \mathrm{e}$.

30. Waissengrin B, Agbarya A, Safadi E, Padova H and Wolf I. Short-term safety of the BNT162b2 mRNA COVID-19 vaccine in patients with cancer treated with immune checkpoint inhibitors. Lancet Oncol. 2021; 22: 581-3.

31. Addeo A, Shah P, Bordry N, et al. Immunogenicity of SARS-CoV-2 messenger RNA vaccines in patients with cancer. Cancer Cell. 2021; 39: 1-8.

32. Palich R, Veyry M, Marot $S$, et al. Weak immunogenicity after a single dose of SARS-CoV-2 mRNA vaccine in treated cancer patients. Ann Oncol. 2021; 32: 1051-3.

33. Khoury D, Cromer D, Reynaldi A, et al. Neutralizing antibody levels are highly predictive of immune protection from symptomatic SARS-CoV-2 infection. Nat Med. 2021; 27: 1205-11.

34. Alizon S, Haim-Boukobza S, Foulongne V, et al. Rapid spread of the SARS-CoV-2 Delta variant in some French regions, June 2021. Euro Surveill 2021; 26: 2100573.

35. Davies N, Abbott S, Barnard R, et al. Estimated transmissibility and impact of SARS-CoV-2 lineage B.1.1.7 in England. Science 2021; 372: eabg3055.

36. Jones T, Biele G, Mühlemann B, et al. Estimating infectiousness throughout SARSCoV-2 infection course. Science. 2021; 373: eabi5273.

37. Kidd M, Richter A, Best A, et al. S variant SARS CoV 2 lineage B1.1.7 is associated with significantly higher viral loads in samples tested by ThermoFisher TaqPath RT qPCR. J Infect Dis. 2021; 223 1666-70,. 
medRxiv preprint doi: https://doi.org/10.1101/2021.08.12.21261806; this version posted August 13, 2021. The copyright holder for this preprint (which was not certified by peer review) is the author/funder, who has granted medRxiv a license to display the preprint in perpetuity.

It is made available under a CC-BY-NC-ND 4.0 International license.

38. Collier D, Ferreira I, Kotagiri P, et al. Age-related immune response heterogeneity to SARS-CoV-2 vaccine BNT162b2. Nature. 2021; Jun 30. doi: 10.1038/s41586-021-

03739-1. Online ahead of print.

39. Iacono D, Cerbone L, Palombi L, et al. Serological response to COVID-19 vaccination in patients with cancer older than 80 years. J Geriatr Oncol. 2021; S18794068: 00136-3.

40. Barriere J, Chamorey E, Adjtoutah Z, et al. Impaired immunogenicity of BNT162b2 anti SARS-CoV-2 vaccine in patients treated for solid tumors. Ann Oncol. 2021; 32: 1053-5.

41. Amir Massarweh A, Eliakim-Raz N, Stemmer A, et al. Evaluation of Seropositivity Following BNT162b2 Messenger RNA Vaccination for SARS-CoV-2 in Patients Undergoing Treatment for Cancer. JAMA Oncol. 2021; May 28: e212155. .

42. Gavriatopoulou M, Terpos E, Kastritis E, et al. Low neutralizing antibody responses in WM, CLL and NHL patients after the first dose of the BNT162b2 and AZD1222 vaccine. Clin Exper Med. 2021; 234: 1-5.

43. Boyarsky B, Werbel W, Avery R, et al. Antibody Response to 2-Dose SARS-CoV-2 mRNA Vaccine Series in Solid Organ Transplant Recipients. JAMA 2021; 325: 2204-06.

44. Lim S, Campbell N, Johnson $\mathrm{M}$, et al. Antibody responses after SARS-CoV-2 vaccination in patients with lymphoma. Lancet Hematol. 2021; 8: e542-e4. .

45. Herishanu Y, Avivi I, Aharon A, et al. Efficacy of the BNT162b2 mRNA COVID-19 Vaccine in Patients with Chronic Lymphocyti Leukemia. Blood. 2021; 137: 3165-73. .

46. Van Oekelen 0, Gleason C, Agte S, et al. Highly variable SARS-CoV-2 spike antibody responses to two doses of COVID-19 RNAvaccination in patients with multiple myeloma. Cancer Cell. 2021; S1535-6108: 00336-6.

47. Kamar N, Abravanel F, Marion O, Couat C, Izopet J and Del Bello A. Three Doses of an mRNA Covid-19 Vaccine in Solid-Organ Transplant Recipients. New Engl J Med. 2021; NEJMc2108861. DOI: 10.1056/NEJMc2108861 Online ahead of print 
medRxiv preprint doi: https://doi.org/10.1101/2021.08.12.21261806; this version posted August 13, 2021. The copyright holder for this preprint (which was not certified by peer review) is the author/funder, who has granted medRxiv a license to display the preprint in perpetuity.

Fig. $1 \mathrm{~A}$

\section{Anti-SARS-CoV-2 Spike IgG \\ in vaccinated patients with thoracic cancer}

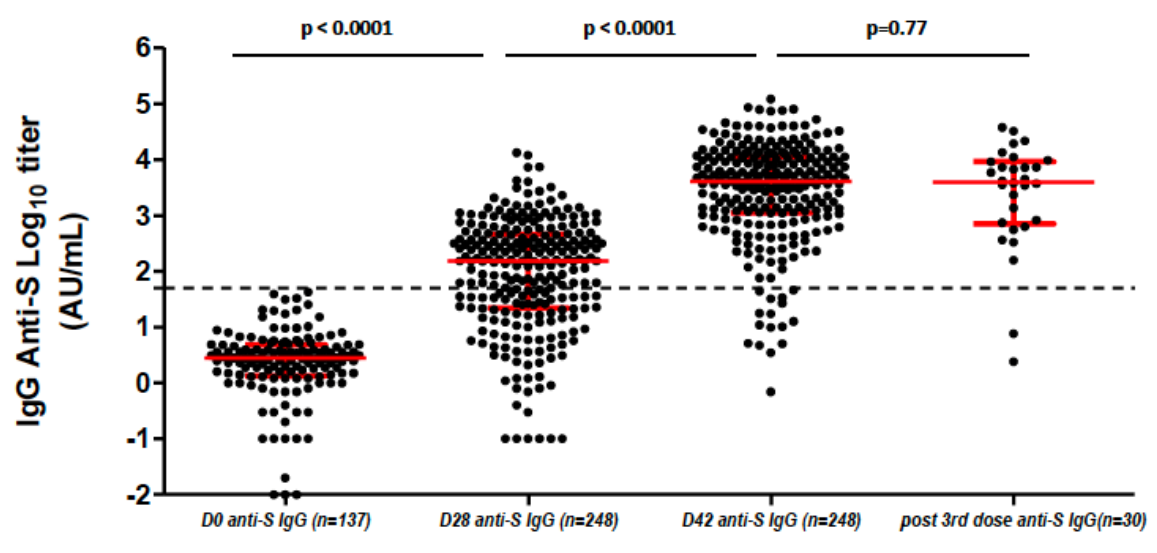

Fig. 1B

Anti-SARS-CoV-2 Spike lgG
28 days after first

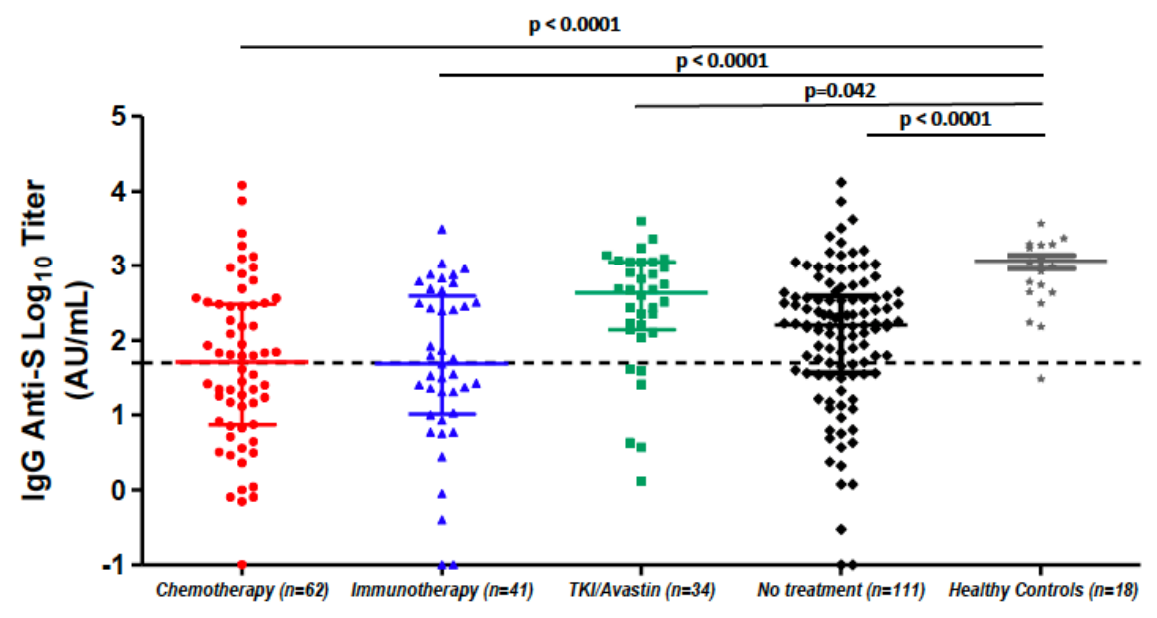

Fig. $1 \mathrm{C}$

Anti-SARS-CoV-2 Spike lgG

42 days after first shot

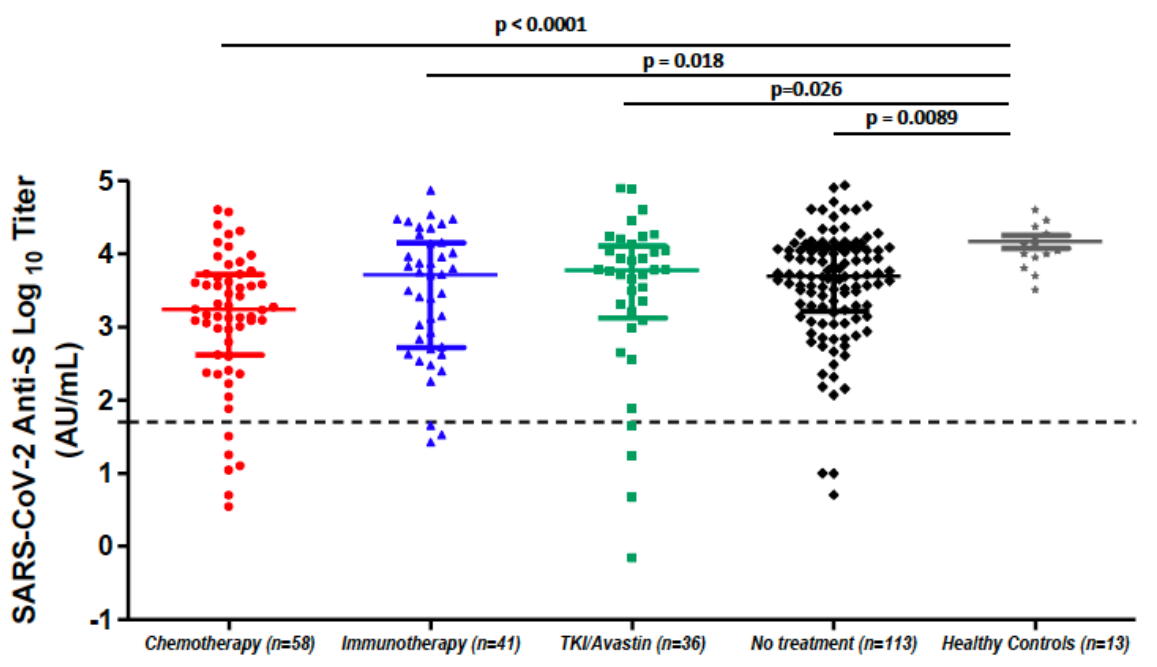


medRxiv preprint doi: https://doi.org/10.1101/2021.08.12.21261806; this version posted August 13, 2021. The copyright holder for this preprint (which was not certified by peer review) is the author/funder, who has granted medRxiv a license to display the preprint in perpetuity.

It is made available under a CC-BY-NC-ND 4.0 International license.

Fig. 2
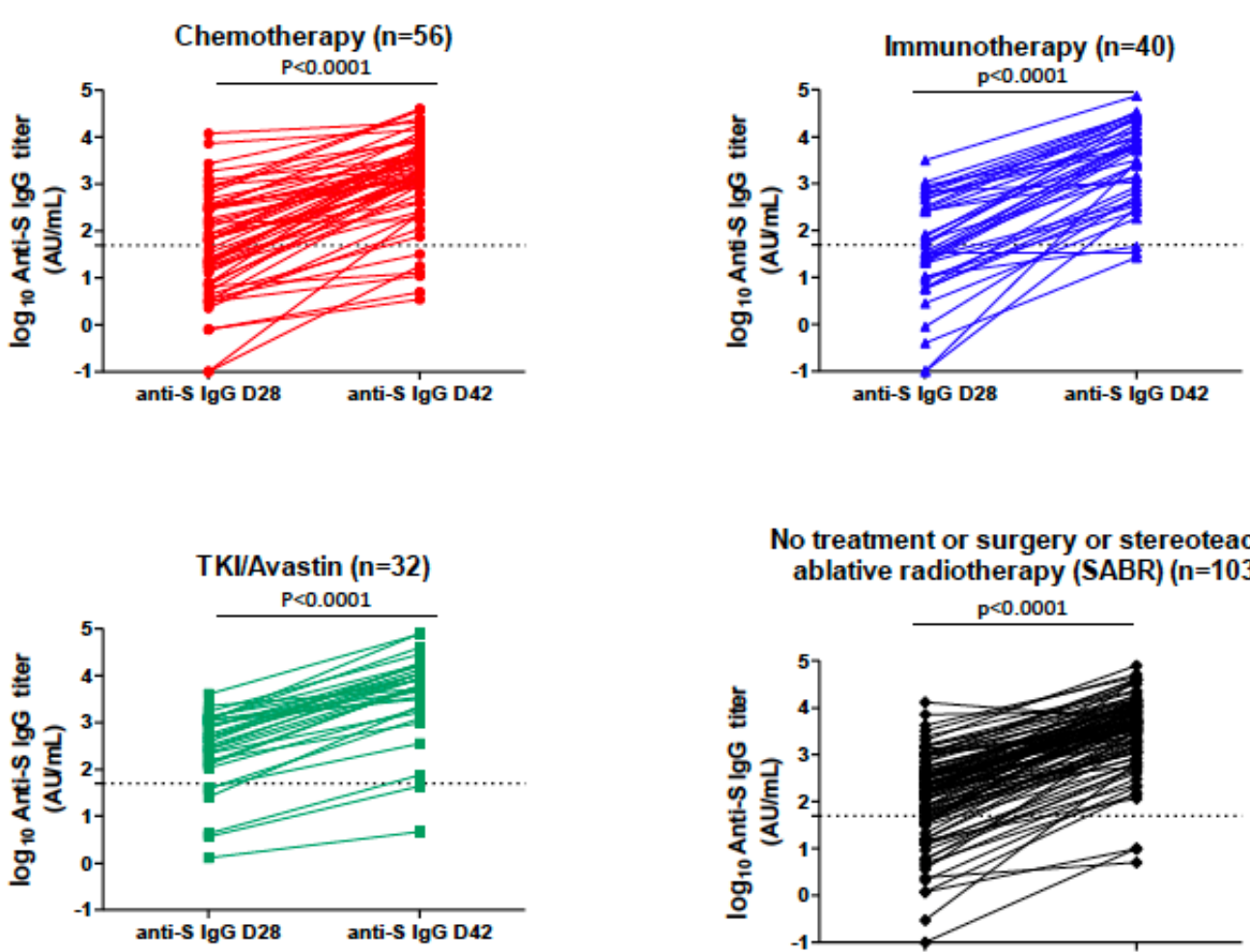

No treatment or surgery or stereoteactic ablative radiotherapy (SABR) $(n=103)$

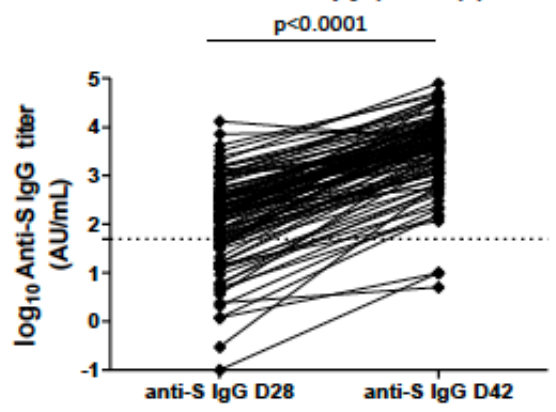


medRxiv preprint doi: https://doi.org/10.1101/2021.08.12.21261806; this version posted August 13, 2021. The copyright holder for this preprint (which was not certified by peer review) is the author/funder, who has granted medRxiv a license to display the preprint in perpetuity.

It is made available under a CC-BY-NC-ND 4.0 International license .

Fig. 3A

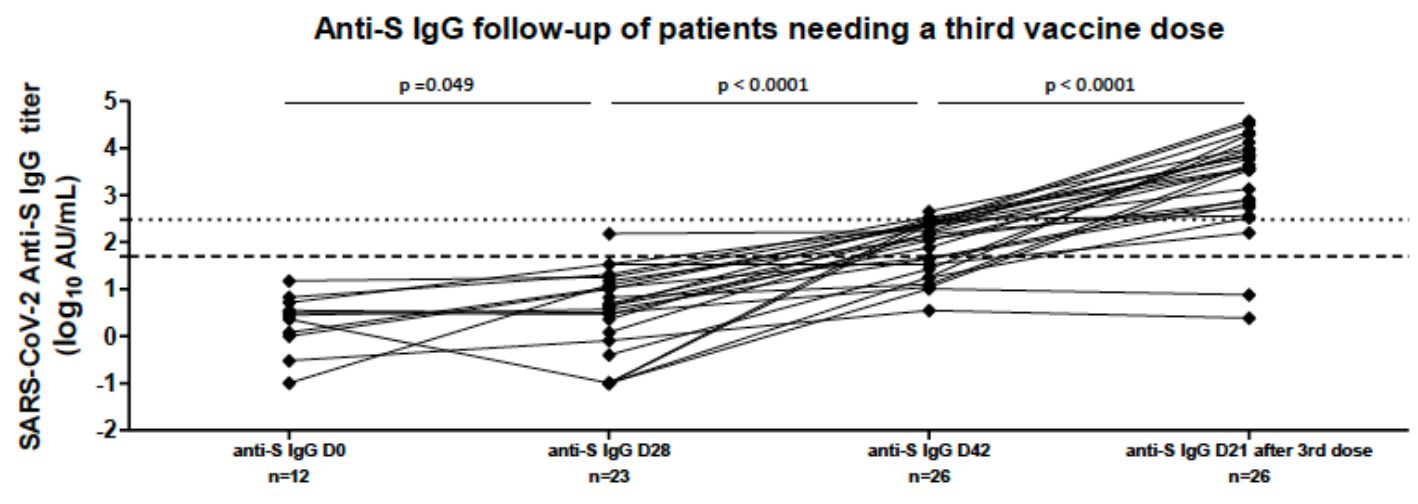

\section{Anti-S IgG in patients receiving \\ 2 or 3 doses according to their anti-S IgG titer at D42}

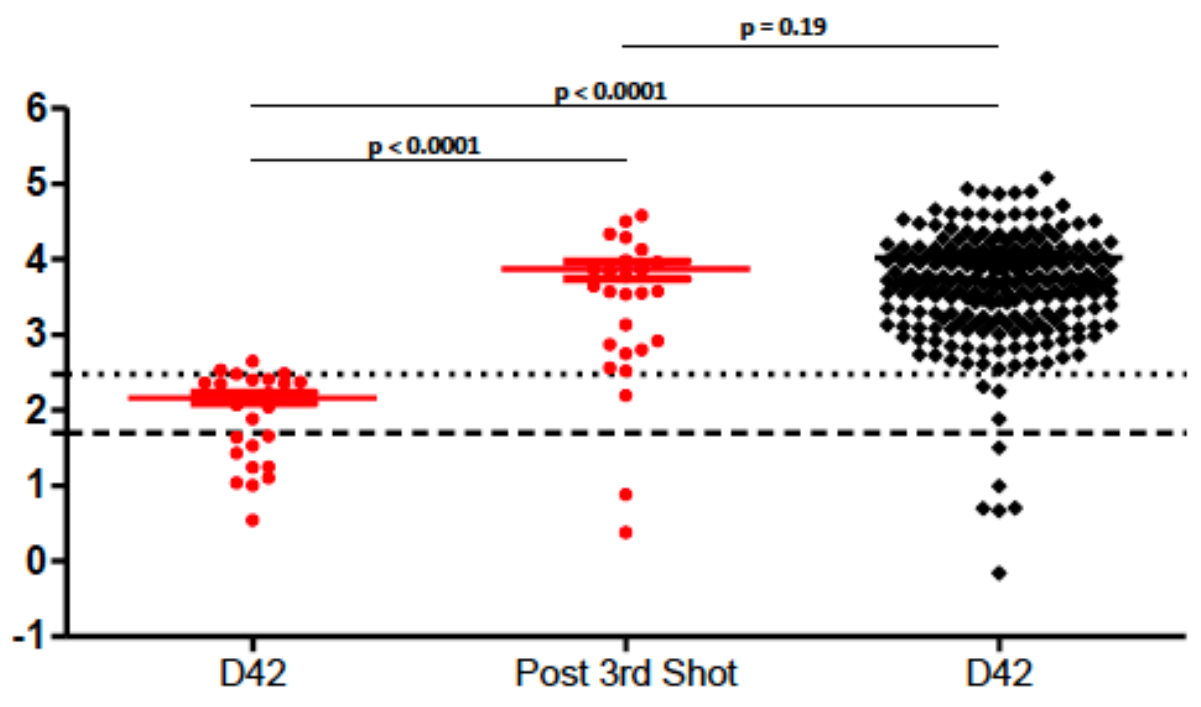

- Patients with 3 vaccine doses $(n=26)$

- Patients with 2 vaccine doses $(n=222)$ 
medRxiv preprint doi: https://doi.org/10.1101/2021.08.12.21261806; this version posted August 13, 2021. The copyright holder for this preprint (which was not certified by peer review) is the author/funder, who has granted medRxiv a license to display the preprint in perpetuity.

It is made available under a CC-BY-NC-ND 4.0 International license.

Table 1: Patient clinical and demographic characteristics at baseline

\begin{tabular}{|c|c|}
\hline Patients $(n=306)$ & \\
\hline $\begin{array}{l}\text { Age (years) } \\
\text { median (range, years) } \\
<70 \\
70-79 \\
\geq \mathbf{8 0}\end{array}$ & $\begin{array}{c}67(27-92) \\
180(58.9 \%) \\
95(31 \%) \\
31(10.1 \%)\end{array}$ \\
\hline $\begin{array}{l}\text { Gender } \\
\text { Male } \\
\text { Female }\end{array}$ & $\begin{array}{l}181(59.2 \%) \\
125(40.8 \%)\end{array}$ \\
\hline $\begin{array}{l}\text { Body mass index } \\
\text { median, } \mathrm{Kg} / \mathrm{m}^{2}(\mathrm{Q} 1-\mathrm{Q})\end{array}$ & $24.9(21.8-27.9)$ \\
\hline Histology & \\
\hline Lung Non-SCC & $211(68.9 \%)$ \\
\hline Lung SCC & $49(16 \%)$ \\
\hline Lung NSCLC & $260(84.9 \%)$ \\
\hline Lung SCLC & $22(7.2 \%)$ \\
\hline Pleural mesothelioma & $13(4.2 \%)$ \\
\hline others* & $11(3.5 \%)$ \\
\hline $\begin{array}{l}\text { Last treatment received }<3 \text { months: } \\
\text { - chemo-based regimen } \\
\text { - immunotherapy alone } \\
\text { - oral TKI or bevacizumab alone } \\
\text { - no systemic treatment } \\
\text { (radiotherapy, surgery, and complete } \\
\text { response) }\end{array}$ & $\begin{array}{c}74(24.2 \%) \\
48(15.7 \%) \\
43(14 \%) \\
141(46.1 \%)\end{array}$ \\
\hline $\begin{array}{l}\text { Chronic radiation pneumonitis } \\
\text { yes } \\
\text { no }\end{array}$ & $\begin{array}{c}37(12.1 \%) \\
269(87.9 \%)\end{array}$ \\
\hline $\begin{array}{l}\text { Previous thoracic surgery } \\
\text { Pneumonectomy }\end{array}$ & $\begin{array}{l}89(29 \%) \\
6(1.95 \%)\end{array}$ \\
\hline
\end{tabular}


medRxiv preprint doi: https://doi.org/10.1101/2021.08.12.21261806; this version posted August 13, 2021. The copyright holder for this preprint (which was not certified by peer review) is the author/funder, who has granted medRxiv a license to display the preprint in perpetuity.

\begin{tabular}{|c|c|}
\hline $\begin{array}{l}\text { Lobectomy or sub-lobar resection } \\
\text { Thymectomy or mediastinal tumor } \\
\text { resection }\end{array}$ & $\begin{array}{c}79(25.8 \%) \\
4(1.3 \%)\end{array}$ \\
\hline \multicolumn{2}{|l|}{ Duration of disease: } \\
\hline $\begin{array}{l}\text { Median, months }(\mathrm{Q} 1-\mathrm{Q} 3) \\
\geq 12 \text { months } \\
<12 \text { months }\end{array}$ & $\begin{array}{c}17.3(6.4-35.3) \\
189 \\
117\end{array}$ \\
\hline $\begin{array}{l}\text { Chronic corticosteroid treatment } \\
\text { - yes } \\
\text { - no }\end{array}$ & $\begin{array}{c}20(6.5 \%) \\
286(93.5 \%)\end{array}$ \\
\hline $\begin{array}{l}\text { Disease extent } \\
\text { - Metastatic } \\
\text { - Local or loco-regional }\end{array}$ & $\begin{array}{l}175(57.2 \%) \\
131(42.8 \%)\end{array}$ \\
\hline $\begin{array}{l}\text { Disease status } \\
\text { - Response or stable } \\
\text { - Progressive }\end{array}$ & $\begin{array}{c}211(69.0 \%) \\
95(31.0 \%)\end{array}$ \\
\hline $\begin{array}{l}\text { T-lymphocyte count available at Day } 28 \\
\text { Median } / \mathrm{mm}^{3}(\mathrm{Q} 1-\mathrm{Q})\end{array}$ & $\begin{array}{c}122(39.9 \%) \\
1129(742-1434)\end{array}$ \\
\hline $\begin{array}{l}\text { CD4+ count available at Day } 28 \\
\text { Median } / \mathrm{mm}^{3}(\mathrm{Q} 1-\mathrm{Q} 3)\end{array}$ & $\begin{array}{c}122(39.9 \%) \\
596(345-853)\end{array}$ \\
\hline $\begin{array}{l}\text { COVID-19 history before first } \\
\text { vaccination } \\
\text { - yes } \\
\text { - no }\end{array}$ & $\begin{array}{c}19(6.2 \%) \\
287(93.8 \%)\end{array}$ \\
\hline $\begin{array}{l}\text { Type of vaccine } \\
\text { Pfizer BNT } 162 \mathrm{~b} 2\end{array}$ & 302 \\
\hline Moderna 1273 & 1 \\
\hline Astra-Zeneca ChAdOx1 nCOVID19 & 3 \\
\hline
\end{tabular}

* five thymic carcinomas, four carcinoid tumors, one hemangio-endothelioma, and one hamartochondroma

SCC: squamous cell cancer; NSCLC: non-small-cell lung cancer; SCLC; small-cell lung cancer: RT: radiotherapy; Q: quartile; TKI: tyrosine-kinase inhibitor 
medRxiv preprint doi: https://doi.org/10.1101/2021.08.12.21261806; this version posted August 13, 2021. The copyright holder for this preprint (which was not certified by peer review) is the author/funder, who has granted medRxiv a license to display the preprint in perpetuity. It is made available under a CC-BY-NC-ND 4.0 International license .

\section{Supplemental online Materials}

\section{Peripheral blood mononuclear cells}

Peripheral blood mononuclear cells (PBMCs) were isolated by density gradient centrifugation using Lymphose ${ }^{\mathrm{TM}}(1.077$ ? $\mathrm{g} / \mathrm{ml}$, Biosera, France). $6 \mathrm{ml}$ of whole blood was diluted 1:1 with PBS. $15 \mathrm{ml}$ of Lymphosep was pipetted into 50-ml SepMateTM centrifuge tubes (Stem Cell Technologies), and the diluted blood was layered over the Lymphosep gradient. The tubes were centrifuged for $10 \mathrm{~min}$ at $1200 \times \mathrm{g}$ with break. After centrifugation, PBMCs were collected and washed twice in PBS. For cryopreservation, PBMCs were diluted with $4^{\circ} \mathrm{C}$ heat-inactivated fetal calf serum (FCS, $\mathrm{Gibco}^{\mathrm{TM}}$, Thermo Fischer Scientific) containing $10 \%$ DMSO and stored at $-80^{\circ} \mathrm{C}$ until further use.

The cryopreserved PBMC samples were thawed in a $37^{\circ} \mathrm{C}$ water bath with gently agitation. Thereafter, the cell suspension was resuspended in $10 \mathrm{ml}$ of pre-warmed RPMI 1640 medium (Gibco ${ }^{\text {TM }}$, Thermo Fischer Scientific) supplemented with $10 \%$ heatinactivated FCS and $100 \mathrm{UI} / \mathrm{ml}$ Penicillin/Strepomycin (Gibco ${ }^{\mathrm{TM}}$, Thermo Fischer Scientific). After centrifugation, cells were resuspended in complete RPMI medium and counted using a hematology analyzer XE-5000 (Sysmex, Kobe, Japan).

\section{ELISpot assay}

T cell responses to SARS-CoV-2 vaccination were assessed by IFN- $\gamma$ ELISpot assay using a T-SPOT.COVID kit (Oxford Immunotec, Abingdon, UK). Thawed PBMCs were resuspended at $2.5 \times 10^{6}$ lymphocytes $/ \mathrm{ml}$ in AIMV medium (Thermo Fischer Scientific). PBMCs were seeded (100 $\mu \mathrm{l}$ per well) and stimulated for 16-18 h with a pool of SARS$\mathrm{CoV}-2$ spike peptides at 37 ? ${ }^{\circ} \mathrm{C}, 5 \% \mathrm{CO}_{2}, 95 \%$ humidity. Subsequently, cells were washed off and released IFN $-\gamma$ was detected following the manufacturer's instructions. Spot forming units (SFU) were counted manually using a DX-1 Microscope (Veho, UK). Results were reported as SFU per million lymphocytes. The unspecific background (SFU from negative control wells) was subtracted from experimental readings. We excluded the results if the positive control well (phytohemagglutinin) was negative. The lower limit to indicate a positive response was 32 spots per million lymphocytes.

\section{Enumeration of peripheral blood lymphocytes}

T-(CD3+, CD3+CD4+, CD3+CD8+), B-(CD19+), and Natural Killer (NK)-lymphocyte (CD3negCD160+?CD56+) absolute counts were enumerated by multiparametric flow cytometry of fresh EDTA-anticoagulated whole peripheral blood (PB). PB samples were processed using a BD FACSDuet ${ }^{\mathrm{TM}}$ preparation system integrated with a BD FACSLyric ${ }^{\mathrm{TM}}$ flow cytometer (Becton Dickinson Biosciences, San Jose, CA). Lymphocyte subpopulations were assessed using BD Multitest ${ }^{\mathrm{TM}}$ CD3/CD8/CD45/CD4, BD Multitest ${ }^{\mathrm{TM}}$ CD3/CD16+CD56/CD45/CD19 and BD Trucount ${ }^{\text {TM }}$ tubes for absolute count with a single step "lyse-no-wash" procedure (BD FACS ${ }^{\text {тM } L y s i n g ~ S o l u t i o n) . ~ B D ~ F A C S ~ S u i t e ~}{ }^{\text {TM }}$ Clinical software version 1.4 was used to collect and analyze the data. 
medRxiv preprint doi: https://doi.org/10.1101/2021.08.12.21261806; this version posted August 13, 2021. The copyright holder for this preprint (which was not certified by peer review) is the author/funder, who has granted medRxiv a license to display the preprint in perpetuity.

It is made available under a CC-BY-NC-ND 4.0 International license.

\section{Patient \& serology disposition}

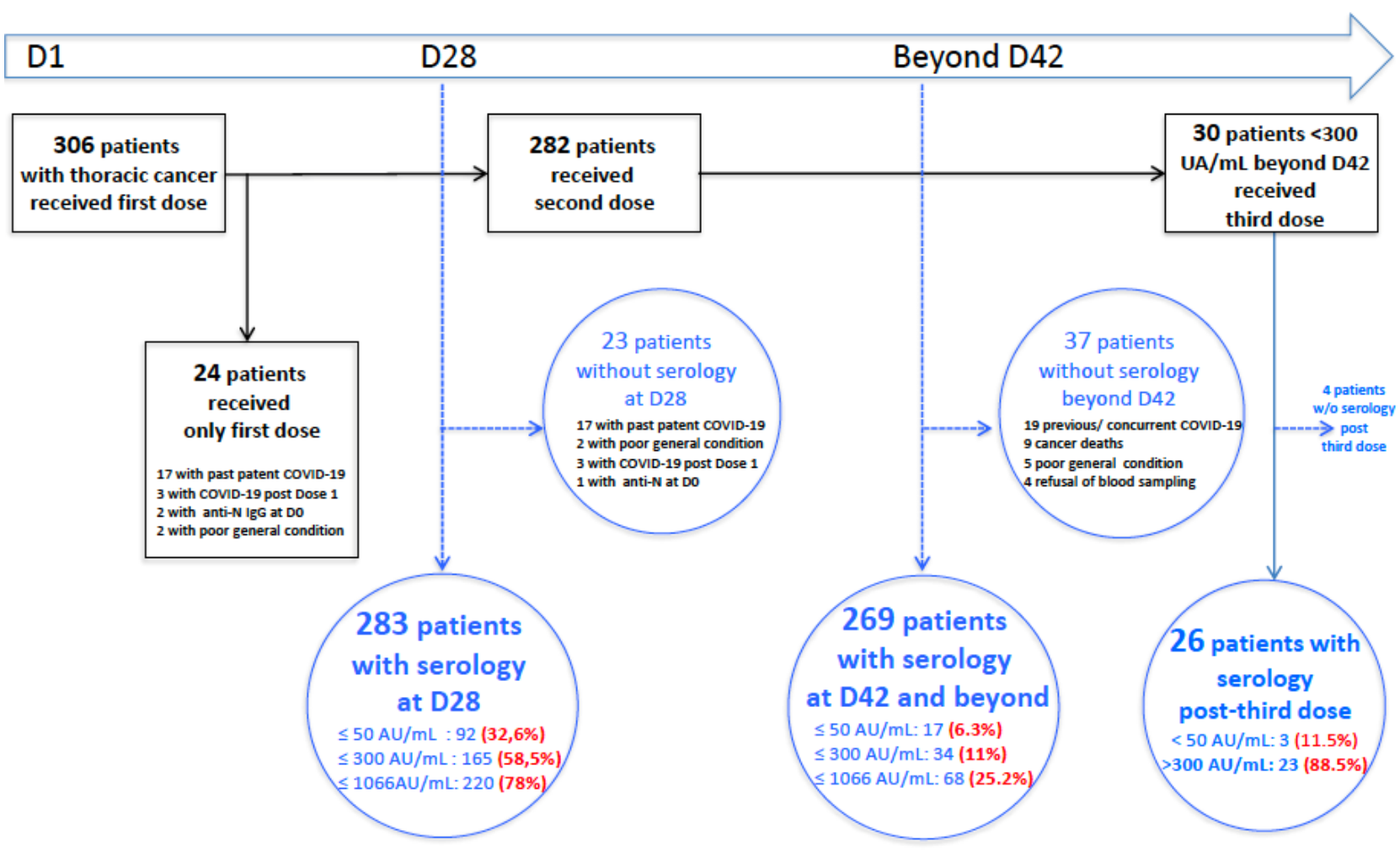

248 patients with serology samplings at D28 and beyond D42

\section{Suppl. Figure 1}


medRxiv preprint doi: https://doi.org/10.1101/2021.08.12.21261806; this version posted August 13, 2021. The copyright holder for this preprint (which was not certified by peer review) is the author/funder, who has granted medRxiv a license to display the preprint in perpetuity. It is made available under a CC-BY-NC-ND 4.0 International license.

Suppl. Fig.2

\section{Spike RBD-pseudoneutralization and anti-S IgG SARS-CoV-2 antibodies correlation}

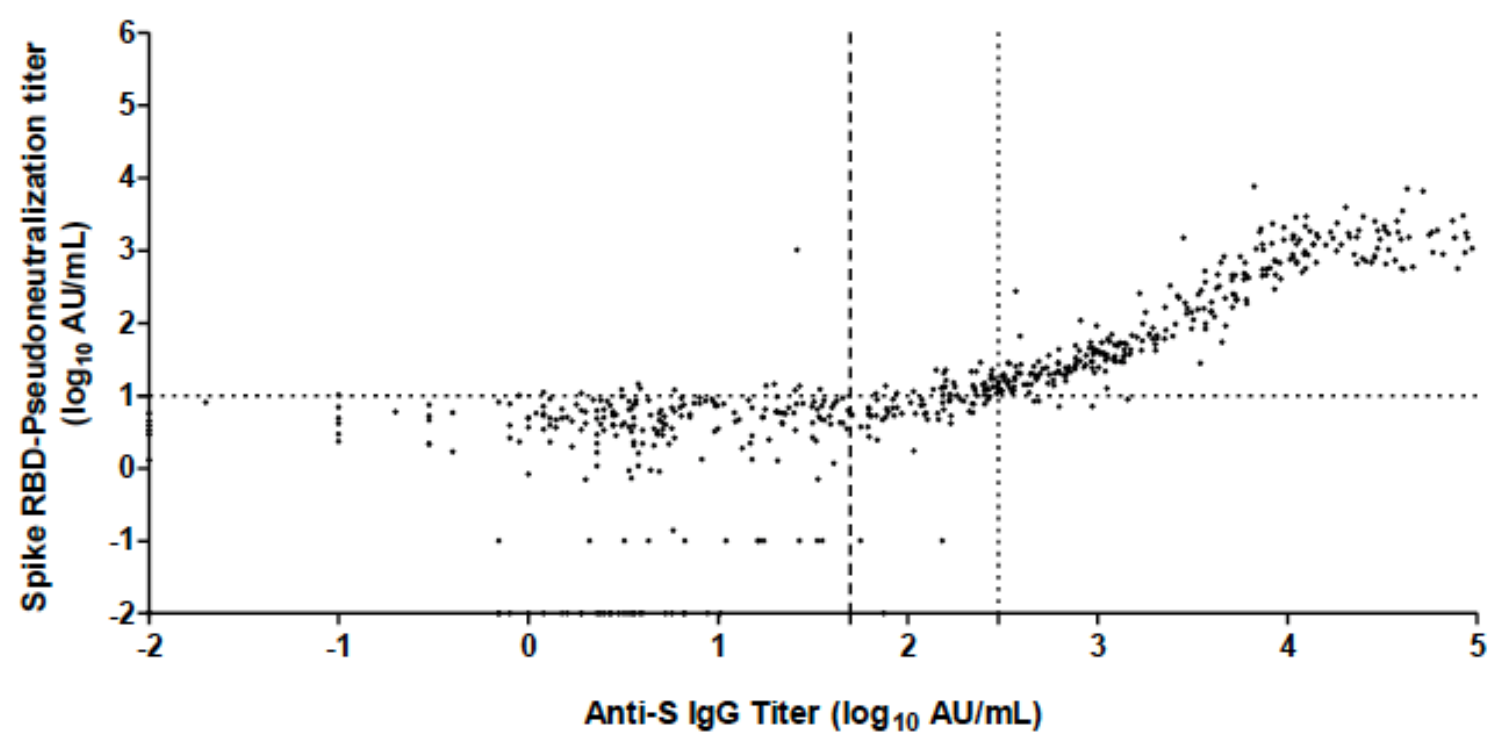


Suppl. Fig. 3

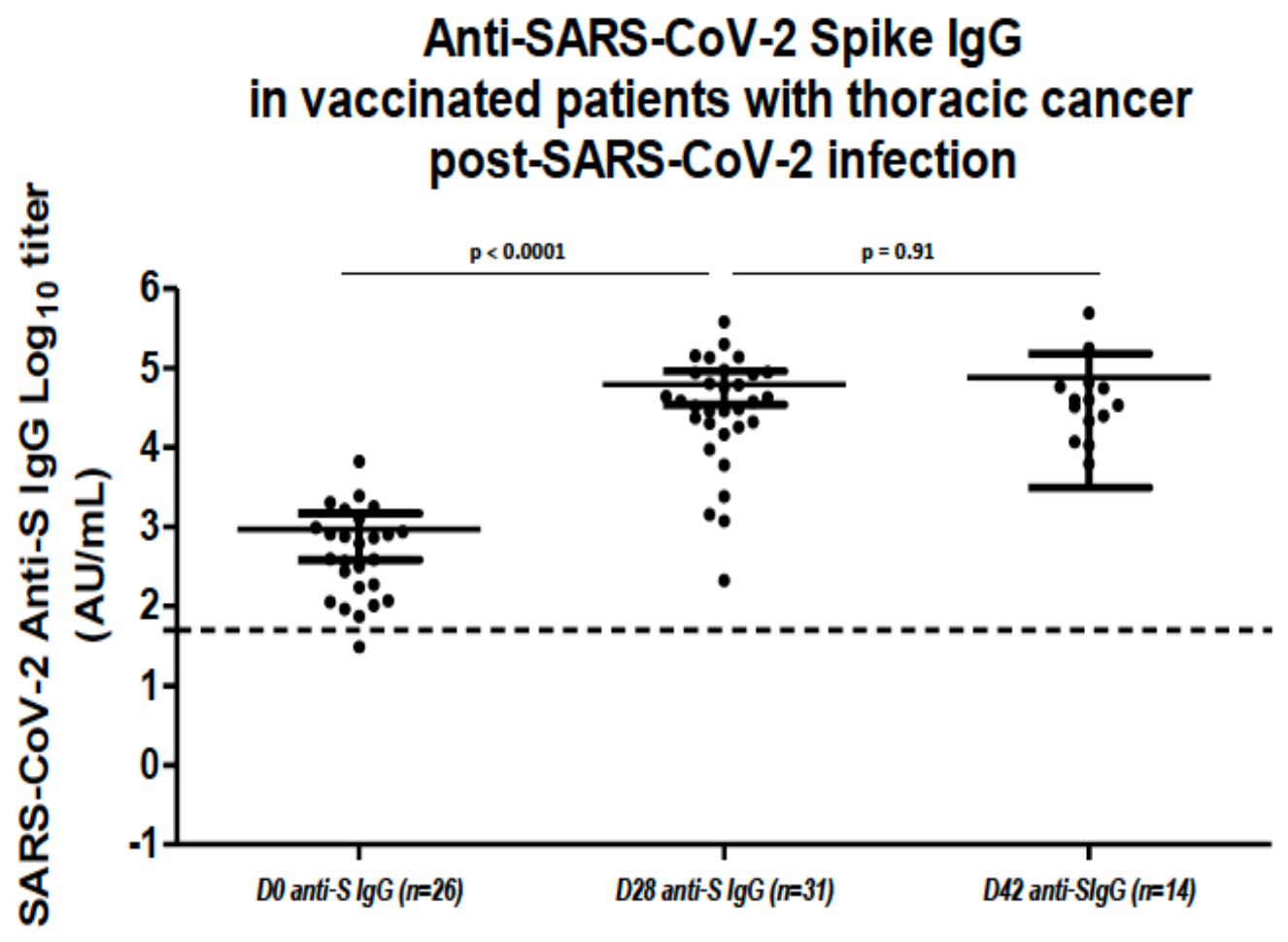


medRxiv preprint doi: https://doi.org/10.1101/2021.08.12.21261806; this version posted August 13, 2021. The copyright holder for this preprint (which was not certified by peer review) is the author/funder, who has granted medRxiv a license to display the preprint in perpetuity.

It is made available under a CC-BY-NC-ND 4.0 International license.

Suppl. Fig 4A

Age and frequencies of immunization at D28

(serum anti-S IgG $\geq 50 \mathrm{AU} / \mathrm{mL}$ )

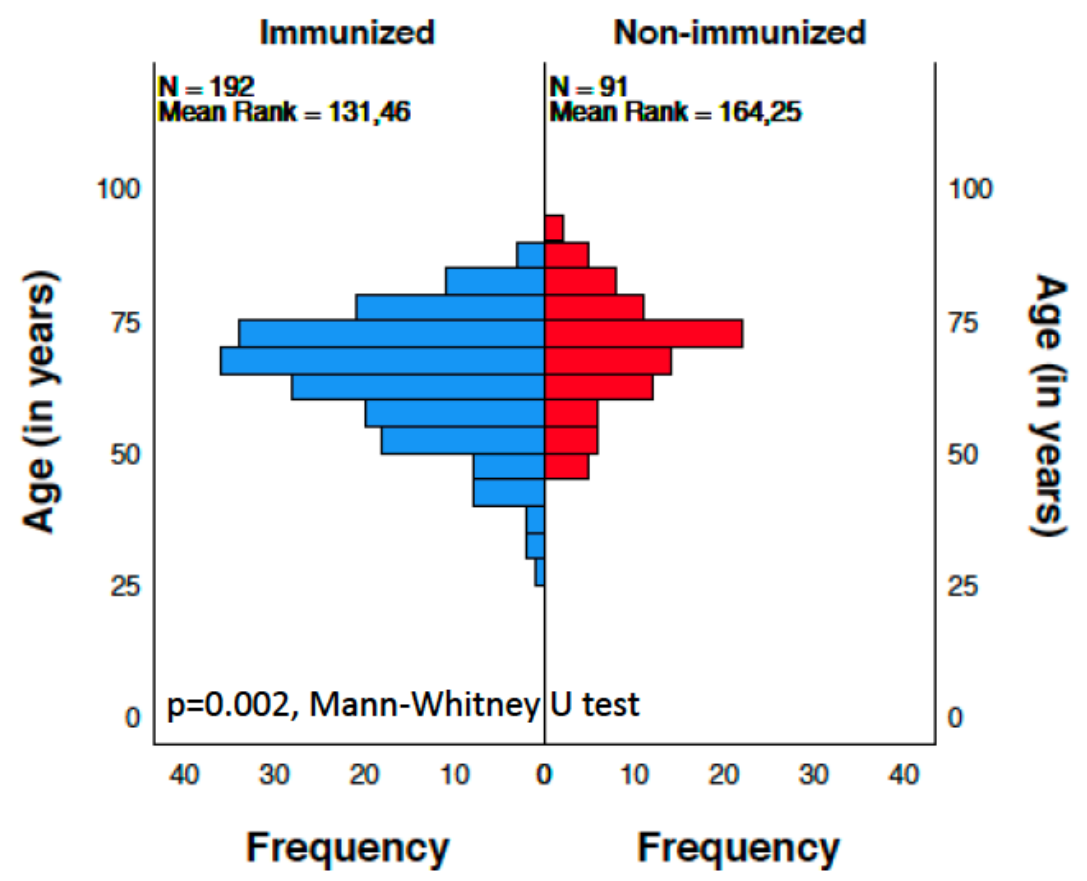

Suppl. Fig 1B T-lymphocytes count and frequencies of immunization at D28 (serum anti-S IgG $\geq 50 \mathrm{AU} / \mathrm{mL}$ ) $\quad n=122$

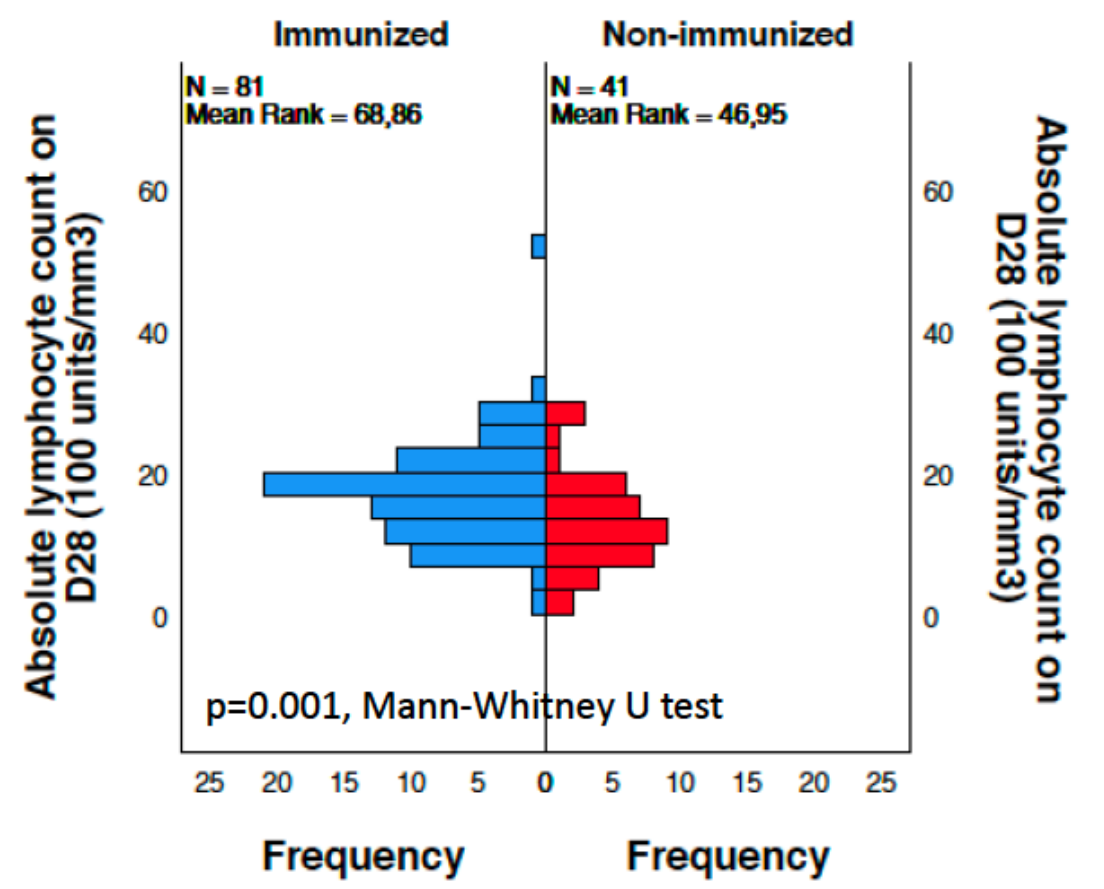


medRxiv preprint doi: https://doi.org/10.1101/2021.08.12.21261806; this version posted August 13, 2021. The copyright holder for this preprint (which was not certified by peer review) is the author/funder, who has granted medRxiv a license to display the preprint in perpetuity.

It is made available under a CC-BY-NC-ND 4.0 International license.

Suppl. Fig 4C

Age and frequencies of immunization at D28

(serum anti-S IgG $\geq 300 \mathrm{AU} / \mathrm{mL}$ )

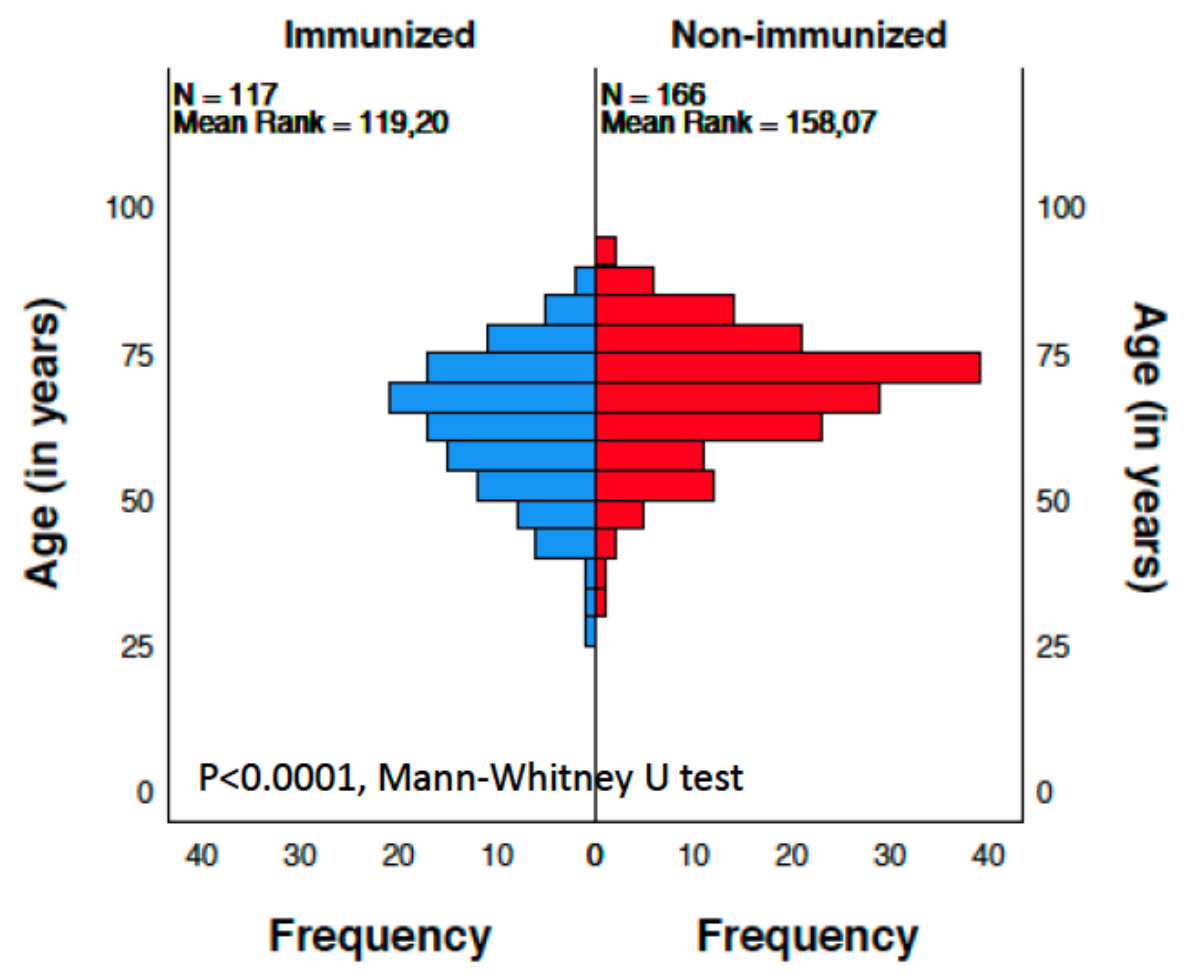


medRxiv preprint doi: https://doi.org/10.1101/2021.08.12.21261806; this version posted August 13, 2021. The copyright holder for this preprint (which was not certified by peer review) is the author/funder, who has granted medRxiv a license to display the preprint in perpetuity.

It is made available under a CC-BY-NC-ND 4.0 International license.

Suppl. Table 1A - Predictors of non-immunization (anti-S IgG antibodies at $50 \mathrm{AU} / \mathrm{mL}$ cut-off) at D28

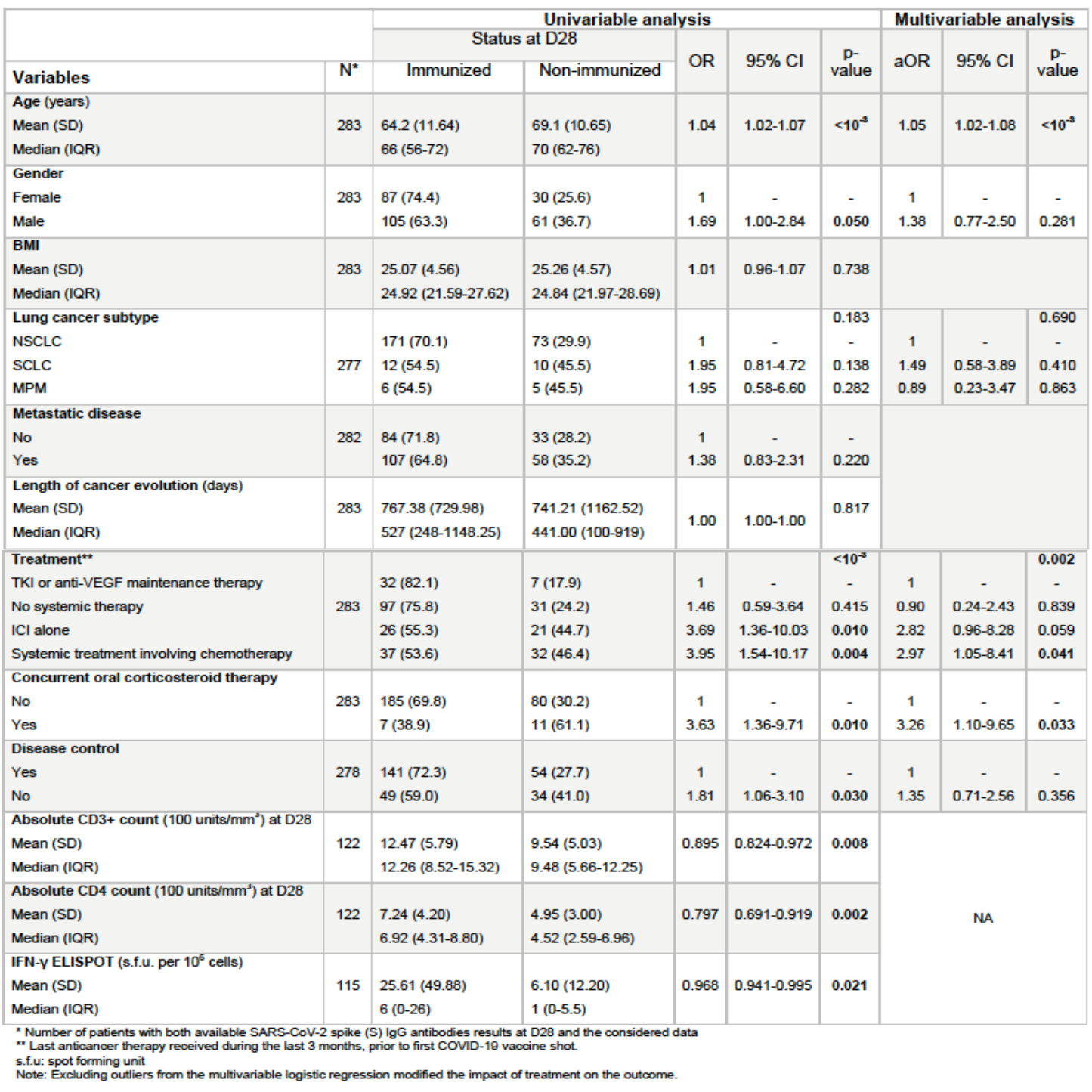


medRxiv preprint doi: https://doi.org/10.1101/2021.08.12.21261806; this version posted August 13, 2021. The copyright holder for this preprint (which was not certified by peer review) is the author/funder, who has granted medRxiv a license to display the preprint in perpetuity.

It is made available under a CC-BY-NC-ND 4.0 International license.

Suppl. Table 1B - Predictors of non-immunization (anti-S IgG antibodies at $300 \mathrm{AU} / \mathrm{mL}$ cut-off) at D28

\begin{tabular}{|c|c|c|c|c|c|c|c|c|c|}
\hline \multirow[b]{3}{*}{ Variables } & \multirow[b]{3}{*}{$\mathrm{N}^{*}$} & \multicolumn{5}{|c|}{ Univariable analysis } & \multicolumn{3}{|c|}{ Multivariable analysis } \\
\hline & & \multicolumn{2}{|c|}{ Status at D28 } & \multirow[b]{2}{*}{ OR } & \multirow{2}{*}{$95 \% \mathrm{Cl}$} & \multirow{2}{*}{$\begin{array}{c}\text { p- } \\
\text { value }\end{array}$} & \multirow[b]{2}{*}{$\mathrm{aOR}$} & \multirow[b]{2}{*}{$95 \% \mathrm{Cl}$} & \multirow{2}{*}{$\begin{array}{c}\text { p- } \\
\text { value }\end{array}$} \\
\hline & & Immunized & Non-immunized & & & & & & \\
\hline $\begin{array}{l}\text { Age (years) } \\
\text { Mean (SD) } \\
\text { Median (IQR) }\end{array}$ & 283 & $\begin{array}{l}62.6(11.82) \\
64(54-70)\end{array}$ & $\begin{array}{l}68(10.82) \\
69(61-75)\end{array}$ & 1.04 & $1.02-1.07$ & $<10^{-3}$ & 1.05 & $1.02-1.07$ & $<10^{-3}$ \\
\hline $\begin{array}{l}\text { Gender } \\
\text { Female } \\
\text { Male }\end{array}$ & 283 & $\begin{array}{l}58(49.6) \\
59(35.5)\end{array}$ & $\begin{array}{l}59(50.4) \\
107(64.5)\end{array}$ & $\begin{array}{c}1 \\
1.78\end{array}$ & $\begin{array}{c}- \\
1.10-2.89\end{array}$ & 0.019 & 1.58 & $0.93-2.70$ & 0.089 \\
\hline $\begin{array}{l}\text { BMI } \\
\text { Mean (SD) } \\
\text { Median (IQR) }\end{array}$ & 283 & $\begin{array}{l}25.19(4.59) \\
25.07(21.85-27.18)\end{array}$ & $\begin{array}{l}25.09(4.54) \\
24.78(21.90-28.43)\end{array}$ & 0.99 & $0.95-1.05$ & 0.855 & & & \\
\hline $\begin{array}{l}\text { Lung cancer subtype } \\
\text { NSCLC } \\
\text { MPM } \\
\text { SCLC }\end{array}$ & 277 & $\begin{array}{l}107(43.9) \\
3(27.3) \\
4(18.2)\end{array}$ & $\begin{array}{l}137(56.1) \\
8(72.7) \\
18(81.8)\end{array}$ & $\begin{array}{c}1 \\
2.08 \\
3.52\end{array}$ & $\begin{array}{c}- \\
1.16-10.69 \\
0.54-8.04\end{array}$ & $\begin{array}{c}0.054 \\
- \\
0.287 \\
0.027\end{array}$ & $\begin{array}{c}1 \\
1.28 \\
2.81\end{array}$ & $\begin{array}{c}- \\
0.31-5.32 \\
0.89-8.86\end{array}$ & $\begin{array}{c}0.204 \\
- \\
0.731 \\
0.077\end{array}$ \\
\hline $\begin{array}{l}\text { Metastatic disease } \\
\text { Yes } \\
\text { No }\end{array}$ & 282 & $\begin{array}{l}68(41.2) \\
48(41.0)\end{array}$ & $\begin{array}{l}97(58.8) \\
69(59.0)\end{array}$ & $\begin{array}{c}1 \\
1.01\end{array}$ & $0.62-1.63$ & $\begin{array}{c}- \\
0.975\end{array}$ & & & \\
\hline $\begin{array}{l}\text { Length of cancer evolution (days) } \\
\text { Mean (SD) } \\
\text { Median (IQR) }\end{array}$ & 283 & $\begin{array}{l}772.66(634.14) \\
599(286-1195)\end{array}$ & $\begin{array}{l}749.31(1035.04) \\
475.5(133.75-938.5)\end{array}$ & 1.00 & $1.00-1.00$ & 0.828 & & & \\
\hline $\begin{array}{l}\text { Treatment } \\
\text { TKI or anti-VEGF maintenance therapy } \\
\text { No systemic therapy } \\
\mathrm{ICl} \text { alone } \\
\text { Systemic treatment involving chemotherapy }\end{array}$ & 283 & $\begin{array}{l}23(59.0) \\
55(43.0) \\
17(36.2) \\
22(31.9)\end{array}$ & $\begin{array}{l}16(41.0) \\
73(57.0) \\
30(63.8) \\
47(68.1)\end{array}$ & $\begin{array}{c}1 \\
1.91 \\
2.54 \\
3.07\end{array}$ & $\begin{array}{c}- \\
0.92-3.95 \\
1.06-6.07 \\
1.36-6.94\end{array}$ & $\begin{array}{c}0.047 \\
- \\
0.082 \\
0.037 \\
0.007\end{array}$ & $\begin{array}{c}1 \\
1.41 \\
1.94 \\
3.07\end{array}$ & $\begin{array}{c}- \\
0.63-3.13 \\
0.76-4.97 \\
1.36-6.94\end{array}$ & $\begin{array}{c}0.187 \\
- \\
0.403 \\
0.165 \\
0.048\end{array}$ \\
\hline $\begin{array}{l}\text { Concurrent oral corticosteroid therapy } \\
\text { No } \\
\text { Yes }\end{array}$ & 283 & $\begin{array}{l}113(42.6) \\
4(22.2)\end{array}$ & $\begin{array}{l}152(57.4) \\
14(77.8)\end{array}$ & $\begin{array}{c}1 \\
2.60\end{array}$ & $\begin{array}{c}- \\
0.83-8.11\end{array}$ & 0.099 & $\begin{array}{c}1 \\
2.07\end{array}$ & $\begin{array}{c}- \\
0.63-6.86\end{array}$ & $\begin{array}{c}- \\
0.232\end{array}$ \\
\hline $\begin{array}{l}\text { Disease control } \\
\text { Yes } \\
\text { No }\end{array}$ & 278 & $\begin{array}{l}31(37.3) \\
86(44.1)\end{array}$ & $\begin{array}{l}52(62.7) \\
109(55.9)\end{array}$ & $\begin{array}{c}1 \\
1.32\end{array}$ & $0.78-2.24$ & $\begin{array}{c}- \\
0.297\end{array}$ & & & \\
\hline $\begin{array}{l}\text { CD3+ T-cell count (100 units/mm }) \text { at D28 } \\
\text { Mean (SD) } \\
\text { Median (IQR) }\end{array}$ & 122 & $\begin{array}{l}12.23(6.23) \\
11.30(8.35-15.16)\end{array}$ & $\begin{array}{l}11.13(5.43) \\
11.11(6.45-14.05)\end{array}$ & 0.967 & $0.905-1.034$ & 0.326 & & & \\
\hline $\begin{array}{l}\text { CD4+ T-cell count ( } 100 \text { units/mm } / \mathrm{m}^{3} \text { ) at D28 } \\
\text { Mean (SD) } \\
\text { Median (IQR) }\end{array}$ & 122 & $\begin{array}{l}7.35(4.92) \\
6.92(4.32-8.56)\end{array}$ & $\begin{array}{l}6.06(3.40) \\
5.33(3.18-9.43)\end{array}$ & 0.922 & $0.834-1.020$ & 0.116 & & NA & \\
\hline $\begin{array}{l}\text { IFN- } \mathrm{y} \text { ELISPOT (s.f.c. per } 10^{6} \text { cells) } \\
\text { Mean (SD) } \\
\text { Median (IQR) }\end{array}$ & 115 & $\begin{array}{l}45.89(66.62) \\
18(4-72)\end{array}$ & $\begin{array}{l}6.99(12.38) \\
1(0-8)\end{array}$ & 0.956 & $0.935-0.978$ & $<10^{-3}$ & & & \\
\hline
\end{tabular}


medRxiv preprint doi: https://doi.org/10.1101/2021.08.12.21261806; this version posted August 13, 2021. The copyright holder for this preprint (which was not certified by peer review) is the author/funder, who has granted medRxiv a license to display the preprint in perpetuity.

It is made available under a CC-BY-NC-ND 4.0 International license.

Suppl. Table 1C - Predictors of non-immunization (anti-S IgG antibodies at $50 \mathrm{AU} / \mathrm{mL}$ cut-off) at D42

\begin{tabular}{|c|c|c|c|c|c|c|c|c|c|}
\hline \multirow[b]{3}{*}{ Variables } & \multirow[b]{3}{*}{$\mathrm{N}^{*}$} & \multicolumn{5}{|c|}{ Univariable analysis } & \multicolumn{3}{|c|}{ Multivariable analysis } \\
\hline & & \multicolumn{2}{|c|}{ Status at D42 } & \multirow{2}{*}{ OR } & \multirow{2}{*}{$95 \% \mathrm{Cl}$} & \multirow{2}{*}{$\begin{array}{c}\text { p- } \\
\text { value }\end{array}$} & \multirow{2}{*}{$\mathrm{aOR}$} & \multirow{2}{*}{$95 \% \mathrm{Cl}$} & \multirow{2}{*}{$\begin{array}{c}\mathrm{p}- \\
\text { value }\end{array}$} \\
\hline & & Immunized & Non-immunized & & & & & & \\
\hline Age (years) & \multirow{3}{*}{269} & & & \multirow{3}{*}{1.07} & \multirow{3}{*}{$1.01-1.12$} & \multirow{3}{*}{0.013} & \multirow{3}{*}{1.09} & \multirow{3}{*}{$1.03-1.15$} & \multirow{3}{*}{0.004} \\
\hline Mean (SD) & & $65.7(10.96)$ & $72.8(12.68)$ & & & & & & \\
\hline Median (IQR) & & $67.5(58-73)$ & $73(63.5-83.5)$ & & & & & & \\
\hline Gender & \multirow{3}{*}{269} & & & \multirow{3}{*}{$\begin{array}{c}1 \\
1.27\end{array}$} & \multirow{3}{*}{$\begin{array}{c}- \\
0.47-3.39\end{array}$} & \multirow{3}{*}{0.640} & & & \\
\hline Male & & $148(94.3)$ & $9(5.7)$ & & & & & & \\
\hline Female & & $104(92.9)$ & $8(7.1)$ & & & & & & \\
\hline BMI & \multirow{3}{*}{263} & & & \multirow{3}{*}{0.94} & \multirow{3}{*}{$0.83-1.05$} & & & & \\
\hline Mean (SD) & & $25.18(4.58)$ & $23.89(4.61)$ & & & 0.263 & 0.96 & $0.84-1.09$ & 0.486 \\
\hline Median (IQR) & & $24.95(21.72-28.19)$ & $23.19(21.10-26.73)$ & & & & & & \\
\hline Lung cancer subtype & & & & & & & & & \\
\hline MPM or SCLC & 263 & $29(93.5)$ & $2(6.5)$ & 1 & - & - & & & \\
\hline NSCLC & & $217(93.5)$ & $15(6.5)$ & 1.00 & $0.22-4.59$ & 1.000 & & & \\
\hline Metastatic disease & & & & & & & & & \\
\hline No & 268 & $112(95.7)$ & $5(4.3)$ & 1 & - & - & & & \\
\hline Yes & & $139(92.1)$ & $12(7.9)$ & 1.93 & $0.66-5.65$ & 0.228 & & & \\
\hline Length of cancer evolution (days) & & & & & & & & & \\
\hline Mean (SD) & 269 & $773.69(931.68)$ & $741.21(480.19)$ & 0.999 & $0.998-1.000$ & 0.100 & 0.999 & $0.998-1.001$ & 0.267 \\
\hline Median (IQR) & & $520(191-1057)$ & $252(61.5-619)$ & & & & & & \\
\hline Treatment ${ }^{* \star}$ & & & & & & 0.136 & & & 0.224 \\
\hline No systemic therapy & & $107(98.2)$ & $2(1.8)$ & 1 & - & - & 1 & - & - \\
\hline $\mathrm{ICl}$ alone & 269 & $40(93.0)$ & $3(7.0)$ & 4.01 & $0.65-24.90$ & 0.136 & 4.27 & $0.77-23.53$ & 0.096 \\
\hline TKI or anti-VEGF maintenance therapy & & $38(90.5)$ & $4(9.5)$ & 5.63 & $0.99-32.00$ & 0.051 & 4.55 & $0.67-30.99$ & 0.051 \\
\hline Systemic treatment involving chemotherapy & & $67(89.3)$ & $8(10.7)$ & 6.39 & $1.32-30.99$ & 0.021 & 6.60 & $1.05-41.62$ & 0.045 \\
\hline Concurrent oral corticosteroid therapy & & & & & & & & & \\
\hline No & 269 & $239(94.8)$ & $13(5.2)$ & 1 & - & - & 1 & - & - \\
\hline Yes & & $13(76.5)$ & $4(23.5)$ & 5.66 & $1.62-19.78$ & 0.007 & 6.22 & $1.41-27.43$ & 0.016 \\
\hline Disease control & & & & & & & & & \\
\hline Yes & 265 & $187(95.9)$ & $8(4.1)$ & 1 & - & - & 1 & - & - \\
\hline No & & $61(87.1)$ & $9(12.9)$ & 3.45 & $1.28-9.33$ & 0.015 & 2.10 & $0.64-6.95$ & 0.224 \\
\hline CD3+ T-cell count $\left(100\right.$ units $\left./ \mathrm{mm}^{3}\right)$ at D42 & & & & & & & & & \\
\hline Mean (SD) & 74 & $10.75(4.99)$ & $4.34(3.15)$ & 0.595 & $0.397-0.891$ & 0.012 & & & \\
\hline Median (IQR) & & $10.73(6.85-13.83)$ & $2.74(2.08-8.11)$ & & & & & & \\
\hline CD4+ T-cell count ( 100 units $\left./ \mathrm{mm}^{3}\right)$ at D42 & & & & & & & & NA & \\
\hline Mean (SD) & 74 & $5.94(2.96)$ & $1.94(0.86)$ & 1 & - & - & & & \\
\hline Median (IQR) & & $5.61(3.23-7.96)$ & $1.85(1.21-2.45)$ & 0.148 & $0.035-0.626$ & 0.009 & & & \\
\hline
\end{tabular}

" number of patients with both available anti-SARS-CoV-2 spike (S) $\lg G$ antibodies at D42 and the considered data

" Last anticancer therapy received during the last 3 months, prior to first COVID-19 vaccine shot

s.f.u: spot forming unit 
medRxiv preprint doi: https://doi.org/10.1101/2021.08.12.21261806; this version posted August 13, 2021. The copyright holder for this preprint (which was not certified by peer review) is the author/funder, who has granted medRxiv a license to display the preprint in perpetuity.

It is made available under a CC-BY-NC-ND 4.0 International license.

Suppl. Table 1D - Predictors of non-immunization (anti-S $\operatorname{lgG}$ at $300 \mathrm{AU} / \mathrm{mL}$ cut-off) at D42

\begin{tabular}{|c|c|c|c|c|c|c|c|c|c|}
\hline \multirow[b]{3}{*}{ Variables } & \multirow[b]{3}{*}{$\mathrm{N}^{*}$} & \multicolumn{5}{|c|}{ Univariable analysis } & \multicolumn{3}{|c|}{ Multivariable analysis } \\
\hline & & \multicolumn{2}{|c|}{ Status at D42 } & \multirow{2}{*}{ OR } & \multirow[b]{2}{*}{$95 \% \mathrm{Cl}$} & \multirow{2}{*}{$\begin{array}{c}\mathrm{p}- \\
\text { value }\end{array}$} & \multirow{2}{*}{$\mathrm{aOR}$} & \multirow[b]{2}{*}{$95 \% \mathrm{Cl}$} & \multirow{2}{*}{$\begin{array}{c}\text { p- } \\
\text { value }\end{array}$} \\
\hline & & Immunized & Non-immunized & & & & & & \\
\hline $\begin{array}{l}\text { Age (years) } \\
\text { Mean (SD) } \\
\text { Median (IQR) }\end{array}$ & 269 & $\begin{array}{l}65.6(10.98) \\
68(58-73)\end{array}$ & $\begin{array}{l}70.2(11.93) \\
70(61.5-81.25)\end{array}$ & 1.04 & $1.00-1.08$ & 0.028 & 1.07 & $1.02-1.11$ & 0.002 \\
\hline $\begin{array}{l}\text { Gender } \\
\text { Female } \\
\text { Male }\end{array}$ & 269 & $\begin{array}{l}99(88.4) \\
136(86.6)\end{array}$ & $\begin{array}{l}13(11.6) \\
21(13.4)\end{array}$ & $\begin{array}{c}1 \\
1.18\end{array}$ & $0.56-2.46$ & $\begin{array}{c}- \\
0.667\end{array}$ & & & \\
\hline $\begin{array}{l}\text { BMI } \\
\text { Mean (SD) } \\
\text { Median (IQR) }\end{array}$ & 269 & $\begin{array}{l}25.26(4.65) \\
24.97(21.72-28.44)\end{array}$ & $\begin{array}{l}23.97(3.91) \\
23.67(21.38-26.96)\end{array}$ & 0.94 & $0.86-1.02$ & 0.124 & 0.97 & $0.88-1.07$ & 0.513 \\
\hline $\begin{array}{l}\text { Lung cancer subtype } \\
\text { NSCLC } \\
\text { MPM or SCLC }\end{array}$ & 263 & $\begin{array}{l}204(87.9) \\
25(80.6)\end{array}$ & $\begin{array}{l}28(12.1) \\
6(19.4)\end{array}$ & $\begin{array}{c}1 \\
1.75\end{array}$ & $\begin{array}{c}- \\
0.66-4.63\end{array}$ & $\begin{array}{c}- \\
0.261\end{array}$ & & & \\
\hline $\begin{array}{l}\text { Metastatic disease } \\
\text { No } \\
\text { Yes }\end{array}$ & 268 & $\begin{array}{l}109(93.2) \\
125(82.8)\end{array}$ & $\begin{array}{l}8(6.8) \\
26(17.2)\end{array}$ & $\begin{array}{c}1 \\
2.83\end{array}$ & $1.23-6.52$ & 0.014 & $\begin{array}{c}1 \\
2.13\end{array}$ & $0.82-5.51$ & 0.119 \\
\hline $\begin{array}{l}\text { Length of cancer evolution (days) } \\
\text { Mean (SD) } \\
\text { Median (IQR) }\end{array}$ & 269 & $\begin{array}{l}801.21(950.09) \\
534(219-1088)\end{array}$ & $\begin{array}{l}413.56(483.37) \\
194(51.5-602)\end{array}$ & 0.999 & $0.998-1.000$ & 0.010 & 0.999 & $0.998-1.000$ & 0.081 \\
\hline $\begin{array}{l}\text { Treatment }{ }^{* *} \\
\text { No systemic therapy } \\
\text { TKI or anti-VEGF maintenance therapy } \\
\text { ICl alone } \\
\text { Systemic treatment involving chemotherapy }\end{array}$ & 269 & $\begin{array}{l}117(92.9) \\
32(86.5) \\
38(86.4) \\
48(77.4)\end{array}$ & $\begin{array}{l}9(7.1) \\
5(13.5) \\
6(13.6) \\
14(22.6)\end{array}$ & $\begin{array}{c}1 \\
2.03 \\
2.05 \\
3.79\end{array}$ & $\begin{array}{c}- \\
0.64-6.49 \\
0.69-6.14 \\
1.54-9.35\end{array}$ & $\begin{array}{c}0.039 \\
- \\
0.232 \\
0.198 \\
0.004\end{array}$ & $\begin{array}{c}1 \\
2.12 \\
2.33 \\
3.14\end{array}$ & $\begin{array}{c}- \\
0.55-8.20 \\
0.66-8.20 \\
1.08-9.13\end{array}$ & $\begin{array}{c}0.209 \\
- \\
0.276 \\
0.187 \\
0.036\end{array}$ \\
\hline $\begin{array}{l}\text { Concurrent oral corticosteroid therapy } \\
\text { No } \\
\text { Yes }\end{array}$ & 269 & $\begin{array}{l}226(89.7) \\
9(52.9)\end{array}$ & $\begin{array}{l}26(10.3) \\
8(47.1)\end{array}$ & $\begin{array}{c}1 \\
7.73\end{array}$ & $\begin{array}{c}- \\
2.74-21.76\end{array}$ & $<10^{-4}$ & $\begin{array}{c}1 \\
6.54\end{array}$ & $\begin{array}{c}- \\
1.95-21.93\end{array}$ & $\begin{array}{c}- \\
0.002\end{array}$ \\
\hline $\begin{array}{l}\text { Disease control } \\
\text { Yes } \\
\text { No }\end{array}$ & 265 & $\begin{array}{l}177(90.8) \\
55(78.6)\end{array}$ & $\begin{array}{l}18(9.2) \\
15(21.4)\end{array}$ & $\begin{array}{c}1 \\
2.68\end{array}$ & $\begin{array}{c}- \\
1.27-5.67\end{array}$ & 0.010 & $\begin{array}{c}1 \\
1.49\end{array}$ & $0.62-3.61$ & $\begin{array}{c}- \\
0.376\end{array}$ \\
\hline $\begin{array}{l}\text { CD3+ T-cell count }\left(100 \text { units } / \mathrm{mm}^{3}\right) \text { at D42 } \\
\text { Mean (SD) } \\
\text { Median (IQR) }\end{array}$ & 74 & $\begin{array}{l}11.08(5.04) \\
11.12(7.24-14.41)\end{array}$ & $\begin{array}{l}5.86(3.36) \\
5.85(2.50-7.70)\end{array}$ & 0.730 & $0.592-0.900$ & 0.003 & & & \\
\hline $\begin{array}{l}\left.\text { CD4+ T-cell count ( } 100 \text { units/mm } / \mathrm{mm}^{3}\right) \\
\text { Mean (SD) } \\
\text { Median (IQR) }\end{array}$ & 74 & $\begin{array}{l}6.11(2.97) \\
5.73(3.82-8.11)\end{array}$ & $\begin{array}{l}3.07(2.03) \\
3.00(1.78-3.43)\end{array}$ & 0.533 & $0.345-0.823$ & 0.005 & & NA & \\
\hline
\end{tabular}

" number of patients with both available anti-SARS-CoV-2 spike (S) IgG antibodies at D42 and the considered data
" Last anticancer therapy received during the last 3 months, prior to first COVID-19 vaccine shot 
HOPITAL BICHAT

46, rue Henri Huchard

75877 PARIS Cedex 18

\section{CEERB PARIS NORD}

\section{IRB00006477}

\section{Comité d'Evaluation de l'Ethique} des projets de Recherche Biomédicale

\section{Adresse pour toute correspondance} sec.ceerb@bch.aphp.fr

Président

- Michel LEJOYEUX michel.lejoyeux@bch.aphp.fr

Membres

- Jean-François ALEXANDRA jean-francois.alexandra@bch.aphp.fr

- Elie AZOULAY elie.azoulay@sls.aphp.fr

- Frédéric BRETAGNOL frederic.bretagnol@bjn.aphp.fr

- Yves CASTIER yves.castier@bch.aphp.fr

- Nathalie CHARNAUX nathalie.charnaux@jvr.aphp.fr

- Christine DOSQUET christine.dosquet@sls.aphp.fr

- Géraldine FALGARONE g.falgarone@avc.aphp.fr

- Antoine GUEDENEY antoine.quedeney@bch.aphp.fr

- Jean GUGLIELMINOTTI jean.guglielminotti@bch.aphp.fr

- Michel KALAMARIDES michel.kalamarides@bjn.aphp.fr

- Hawa KEITA-MEYER hawa.keita@Imr.aphp.fr

- Matthieu LEGRAND matthieu.legrand@Irb.aphp.fr

- Dan LONGROIS dan.longrois@bch.aphp.fr

Dominique LUTON dominique.luton@bch.aphp.fr

- Claire MACABIAU claire.macabiau@noos.fr

- Laurent MANDELBROT

laurent.mandelbrot@Imr.aphp.fr

- Marie-Rose MORO marie-rose.moro@cch.aphp.fr

- Gérard REACH gerard.reach@avc.aphp.fr

- Alain SAUVANET alain.sauvanet@bjn.aphp.fr

- Philippe SOYER philippe.soyer@Irb.aphp.fr

- Anne THONI aumonerie.avicenne@avc.aphp.fr

\section{BICHAT - CLAUDE BERNARD}

\section{Pr Luis TEIXEIRA}

Sénopôle Saint Louis

Equipe 6 "physiopathologie des cancers du sein"

INSERM U976

Université de Paris

Hôpital Saint Louis

Pr Gérard ZALCMAN

Service d'oncologie thoracique, CIC1425, Hôpital Bichat

Dr. Sandra ASSOUN, PHc,

Service d'oncologie thoracique,

CIC1425, Hôpital Bichat

Pr. Diane DESCAMPS,

Service de Virologie,

Hôpital Bichat

Date February 11, 2020

\section{Subject : N $^{\circ}$ CER-2021-72}

Dear Colleague,

The "Comité d'Evaluation de l'Ethique des projets de Recherche Biomédicale (CEERB) Paris Nord" (Institutional Review Board -IRB 00006477- of HUPNVS, Paris 7 University, AP-HP), has reviewed and approved the research project entitled «Multicenter, observational study of anti-Sars-Cov2 vaccine efficacy in patients with malignant pathologies treated in the AP-HP GHU. North" (Pr Luis TEIXEIRA, Pr Gérard ZALCMAN, Dr. Sandra ASSOUN, Pr Diane DESCAMPS, principal investigators) in 2021. This approval covers the entire period during which the project will be developed until its completion.

Yours sincerely.

Pr. Michel LEJOYEUX

Chair of the Institutional Review Board (IRB)

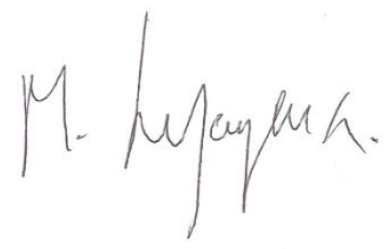

